\title{
CONCEPT
}

\section{Venomous Adversaries: A Reference to Snake Identification, Field Safety, and Bite-Victim First Aid for Disaster-Response Personnel Deploying Into the Hurricane-Prone Regions of North America}

\author{
Edward J. Wozniak DVM, PhD; John Wisser, MS; Michael Schwartz, MD
}

From Texas A\&M University Health Science Center, Institute for Biosciences and Technology, Program for Animal Resources, Houston, TX (Dr Wozniak); Tropical Vision, Alvin, TX (Mr Wisser); and the Centers for Disease Control and Prevention, Agency for Toxic Substance and Disease Registry, Chamblee, GA (Dr Schwartz).

\begin{abstract}
Each hurricane season, emergency-preparedness deployment teams including but not limited to the Office of Force Readiness and Deployment of the US Public Health Service, Federal Emergency Management Agency, Deployment Medical Assistance Teams, Veterinary Medical Assistance Teams, and the US Army and Air Force National Guard are at risk for deploying into hurricane-stricken areas that harbor indigenous hazards, including those posed by venomous snakes. North America is home to 2 distinct families of venomous snakes: 1) Viperidae, which includes the rattlesnakes, copperheads, and cottonmouths; and 2) Elapidae, in which the only native species are the coral snakes. Although some of these snakes are easily identified, some are not, and many rank among the most feared and misunderstood animals. This article specifically addresses all the native species of venomous snakes that inhabit the hurricane-prone regions of North America and is intended to serve as a reference to snake identification, basic field safety procedures, and the currently recommended first-aid measures for snakebite casualties.
\end{abstract}

Key words: snakes, snakebite, envenomation, hurricanes, snake identification

\section{Introduction}

Hurricanes are large tropical cyclones that can have devastating effects on coastal communities and adjacent inland areas. Although much of the damage associated with a hurricane strike is directly attributable to wind, flying debris, storm surge, and the associated floods and tornados, the aftermath associated with the damage to infrastructure and environmental perturbation can also have a major impact on public health and safety. Increased incidences of traumatic injuries, infectious diseases, and reptile and arthropod envenomation cases have been reported in the aftermath of past storms and will undoubtedly be important with future hurricane incidents. ${ }^{1-6}$ Epidemiologic studies have identified emer-

Corresponding author: Edward J. Wozniak DVM, PhD, LCDR, USPHS Inactive Reserve, Texas A\&M University Health Science Center, Institute for Biosciences and Technology, Program For Animal Resources, 2121 W Holcombe Blvd, Houston, TX 77030 (e-mail: ewozniak@lbt.tamhsc.edu). gency-response personnel involved in hurricane rescue and recovery missions as a group who are particularly susceptible to poststorm injuries, including animal bites. ${ }^{1}$ Despite the inherent dangers, each hurricane season numerous rescue personnel from around the country enter into storm-stricken areas blindly in terms of their knowledge of potentially dangerous native fauna and, in many cases, without the benefit of appropriate field safety training. Performance-hindering ophidiophobia, unnecessary worry, and possible delays in bite case management as a result of an offending snake not being promptly and accurately identified could all contribute to less-than-optimal response effectiveness.

Within the United States, the Gulf Coast in its entirety and the Atlantic Coast from southern Florida northward to the level of coastal Maine is the most vulnerable region to hurricanes. These coastlines and the adjacent regions extending 50 to 200 miles inland comprise what is known as the hurricane strike zone of North America. ${ }^{7}$ For the purpose of this article, we have extended the 
inland borders an additional 150 miles to account for the peripheral areas likely to be damaged by the associated floods and tornados. This large geographic area encompasses a wide variety of habitats ranging from the cool deciduous forests of the Northeast to the hot and dry Chihuahuan Desert and is home to a correspondingly wide range of snake genera, species, and subspecies, including 19 venomous varieties. With the exception of Maine, every state in the defined geographic region is inhabited by 1 or more medically significant venomous snake species.

Approximately 7000 snakebites are reported in the continental United States annually. ${ }^{8}$ In 2002, for instance, the American Association of Poison Control Centers reported 6733 calls for snakebites. Of these, 1976 were identified as bites inflicted by nonvenomous species. An additional 125 of the cases involved captive exotic venomous snakes. The remaining 4632 of the reported bites were inflicted by native venomous species. The incidence of snake envenomation predictably varies seasonally. Historically, the incidence of envenomation is often increased in areas freshly perturbed by tropical cyclones. ${ }^{4-6}$ The predominant snake species involved in envenomation cases varies across the different geographic regions and habitats.

The fact that people have difficulty with the accurate identification of snakes is reflected in the large number of reported bites in which the species involved was listed as "unidentified." Retrospective studies on venomous snakebite cases have documented that the rate in which the offending snake species is classified as unidentified can exceed $25 \%$ in some areas. ${ }^{9}$ During the large-scale animal rescue and recovery mission in New Orleans after Hurricane Katrina, over $60 \%$ of the snakes brought into shelter facilities by rescue workers were improperly identified. This is unfortunate with bite cases involving a venomous species; accurate identification of the offending snake can be a valuable piece of information to the attending physician in both monitoring the patient and promptly formulating an effective treatment plan. 8,10 In disaster-stricken areas with widespread structural damage and the potential for escaped exotic venomous species to be loose in the environment, accurate identification can be critical. ${ }^{11}$ Because of the increased likelihood of snake encounters and seeing victims of snakebites in the aftermath of a major storm, it is advisable for personnel deploying into hurricane-stricken areas to become familiar with snake identification methods, basic field safety, and the currently recommended first-aid measures for handling bite cases. The purpose of this article is to provide emergency-response personnel with a comprehensive list of dangerous snake species native to the hurricane-prone regions of North America; to

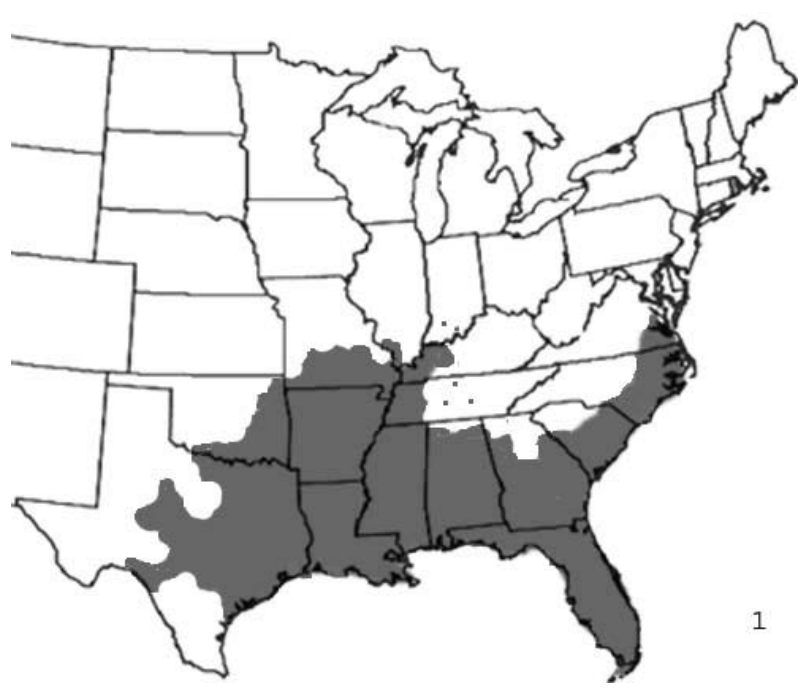

Map 1. The distribution range of the cottonmouth (Agkistrodon piscivorus) within the United States. This map is an approximated summation of the distribution range data for all 3 cottonmouth subspecies and includes data from several field guides and the monograph on the Agkistrodon species complex. ${ }^{13,15-18,20}$

highlight their identifying characteristics, biology, and behaviors; to discuss basic field safety and avoidance methods; and to summarize the current first-aid recommendations for victims of snake envenomation. The distribution maps are all original artwork and represent an approximated summation of data from several published field guides, textbooks, and monographs as well as the field notes of the corresponding author. ${ }^{12-20}$

\section{Family Viperidae}

All the American copperheads, cottonmouths, and rattlesnakes are members of the family Viperidae. Fossil records suggest that this large family of snakes, which includes species as diverse as the giant vipers of Africa (puff adders, gaboon vipers, and rhinoceros vipers) to the comparatively tiny pygmy rattlesnakes of southeastern North America, originated on the Asian continent. ${ }^{12,13,21-24}$ All New World viperids have the bilateral heat-sensitive pit organs and are therefore members of the subfamily Crotalinae. ${ }^{22}$ The common origin for the New World pit viper species complex may account for the reported variable degrees of cross-reactivity of antivenoms with the venoms of genera and species that were not used in its production. ${ }^{25-28}$

The viperid envenomation apparatus consists of a pair of long, hollow, movable maxillary fangs (solenoglyphous dentition). ${ }^{14,22}$ Because fang movement and the ejection of venom are both operated by skeletal muscle, 


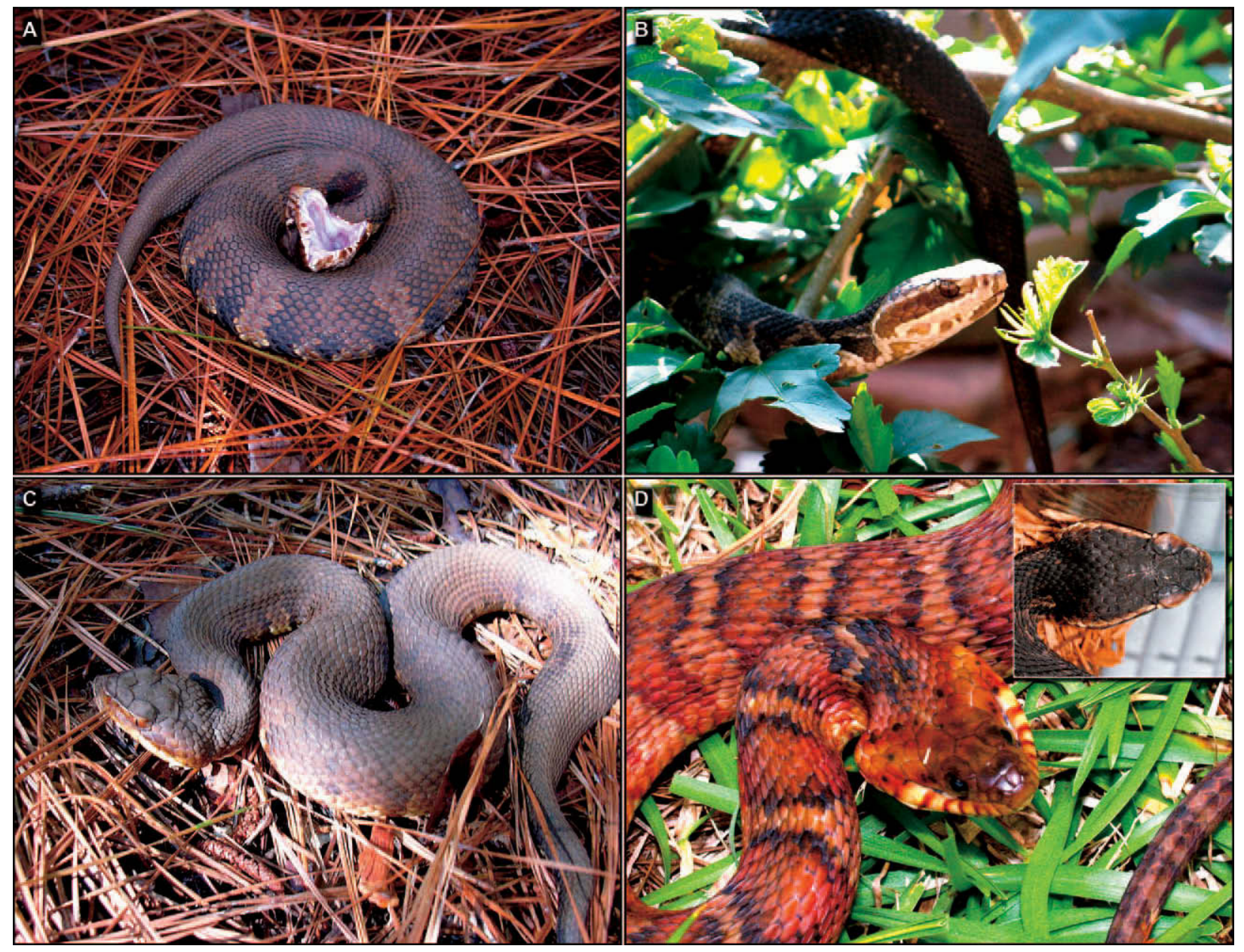

Figure 1. Illustrations of the 3 cottonmouth subspecies in comparison with a potential mimic, the southern water snake (Nerodia fasciata). A. The eastern cottonmouth (Agkistrodon p piscivorus) (photo by John Willson at the Savannah River Ecology Laboratory [SREL]). B. The Florida cottonmouth (Agkistrodon p conanti) (Alachua County, FL) (photo by Edward Wozniak). C. Western cottonmouth (Agkistrodon p leucostoma) (Polk County, TX) (photo by Michael Smith). D. Southern water snake ( $N$ fasciata) (harmless) (photo by John Willson at the SREL). Note the distinct 2-tone coloration, the spadelike shape of the head, the lateral position of the eyes, the vertically elliptical pupils, the cheek stripes, and the loreal pits of the cottonmouths and compare each with the water snake. Whereas the head of an alarmed water snake is distinctly triangular, it has an arrowhead-like shape in comparison with that of the cottonmouth (inset picture in Figure 1D), which retains its spadelike shape even in an enraged individual. Many species of water snakes have large protruding eyes with distinctly round pupils that are medial to the lateral margins of the widened head, unlike any of the 3 cottonmouth species. All these features are helpful in differentiating cottonmouths from water snakes in the field. The medium-sized Florida cottonmouth shown in Figure 1B has taken refuge on a limb protruding from floodwater. Even small amounts of leafy vegetation can effectively conceal snakes. Contact with vegetation protruding from or hanging over floodwater should be avoided.

both are under voluntary control. ${ }^{22}$ In a given bite incident, a snake may or may not use the fangs, and even if it uses the fangs it may not inject venom. Handling, restraining, or agitating snakes by repeated attempts to capture or kill the animals are all factors that can lead to serious envenomation. ${ }^{14}$ Therefore, venomous snakes encountered in the field are best given a wide berth and left alone.

\section{COTTONMOUTHS}

When one thinks about snakes indigenous to the hurricane-prone areas in the eastern United States, the cottonmouth or water moccasin (Agkistrodon piscivorus) is probably the first species to come to mind. The cottonmouth is a large, dark, heavy-bodied snake that ranges throughout most of the southeastern and south-central United States (Map 1). Cottonmouths are the largest 


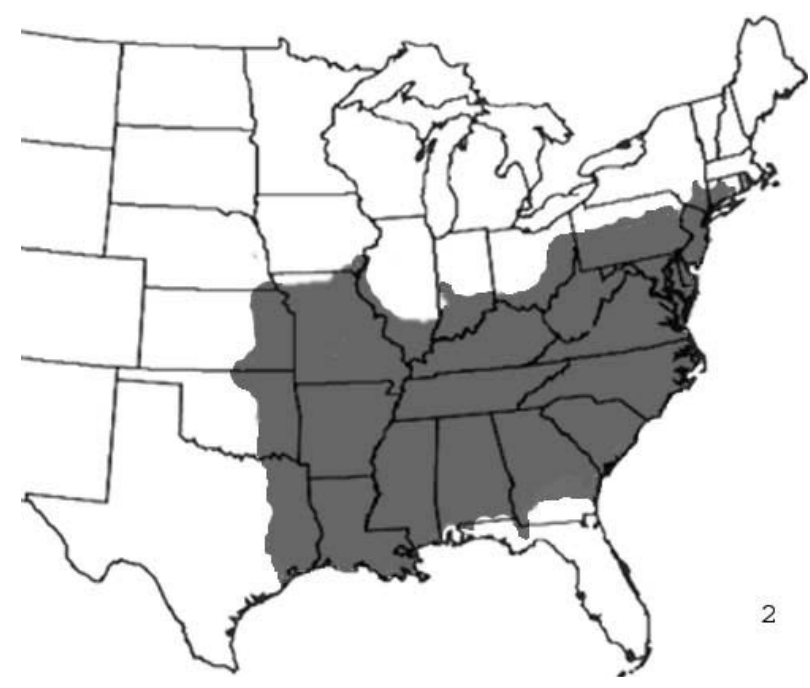

Map 2. The distribution range of the American copperhead (Agkistrodon contortrix) with hourglass-shaped crossbands. This map includes all 3 of the currently recognized copperhead subspecies in this category and represents an approximated summation of data from several field guides and the monograph on the Agkistrodon species complex. ${ }^{13,15-20}$ This map includes distribution data on the Osage copperhead (Agkistrodon c phaeogaster), which is the subspecies that inhabits the northwestern quadrant of the range and is the only copperhead subspecies that does not range into the defined geographic region of concern.

snakes in the New World Agkistrodon species complex and are the only members of the group that are semiaquatic. ${ }^{13}$ Three distinct subspecies are recognized: the eastern cottonmouth, the Florida cottonmouth, and the western cottonmouth.

The ground color of A piscivorus varies from brown to olive to black, and the dorsum of all 3 subspecies is marked with 10 to 17 broad, dark brown, black-edged crossbands with pale centers that often bear 1 or more dark round spots in the centrolateral aspect. All 3 subspecies undergo ontogenetic cutaneous melanization with anteriograde darkening of the body, beginning with the tail. In yearling to adult specimens, this phenomenon typically causes the dorsal pattern to fade and the background color to darken on the caudal aspect of the body, giving the snake a characteristic "2-tone" pattern of body coloration (Figure 1). Learning to recognize this pattern can be helpful in quickly distinguishing most cottonmouths from nonvenomous water snakes in the field. With older adult snakes, however, the advanced degree of melanization can obscure the dorsal pattern over much of the body, causing some individuals to appear almost entirely black. At the other end of the age spectrum, neonatal cottonmouths are often reddish brown with bright yellow or greenish tails and are so strongly

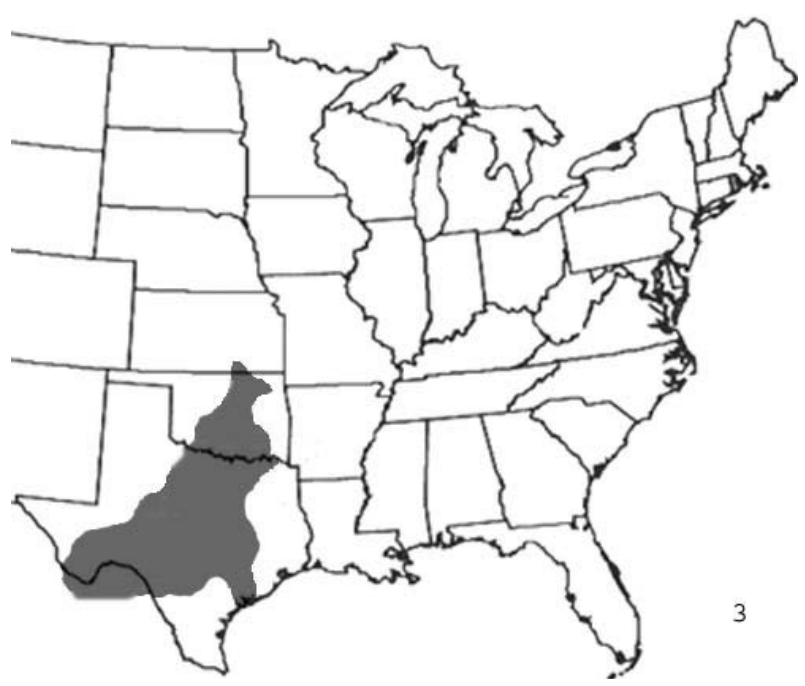

Map 3. The distribution range of the American copperhead (Agkistrodon contortrix) with broad crossbands (Agkistrodon c laticinctus and Agkistrodon c pictigaster). This map is an approximated summation of the distribution ranges for both of the copperhead subspecies in this category and includes data from several field guides and reference books. ${ }^{13,15-20}$ The transpecos copperhead (A c pictigaster) is the only subspecies that ranges across the border into Mexico. ${ }^{17}$

patterned that they are frequently mistaken for copperheads.

The cottonmouth is probably the most frequently misidentified snake in North America, largely because of its frequent confusion with the more common harmless natricine water snakes (Nerodia spp) that are superficially similar in appearance. In addition to the previously described pattern and coloration characteristics, the spadeshaped head bearing supraocular scales that overhang the eyes when viewed from directly above, their gaping behavior, and their habit of vibrating the tail when disturbed are all features that can be helpful in quickly differentiating cottonmouths from harmless natricine water snakes in the field. Other less obvious but distinctive physical characteristics that typify the species include a crown of 9 plates on the dorsal head, a "flattened" or "squared off" rostral profile, the presence of bilateral loreal pit organs, elliptical pupils, and third upper labial scales that extend from the lip to the ventral margins of the eyes. ${ }^{15}$ Many species of nonvenomous water snakes (Nerodia spp) are capable of flattening and widening their head into a distinctly triangular, arrowhead-like shape when alarmed. The sudden change in head shape from a normally narrow profile to the arrowhead-like conformation when alarmed, the medial position of the eyes relative to the lateral head margins, the round pupils, the pointed snout profile, the vertical striping on the 


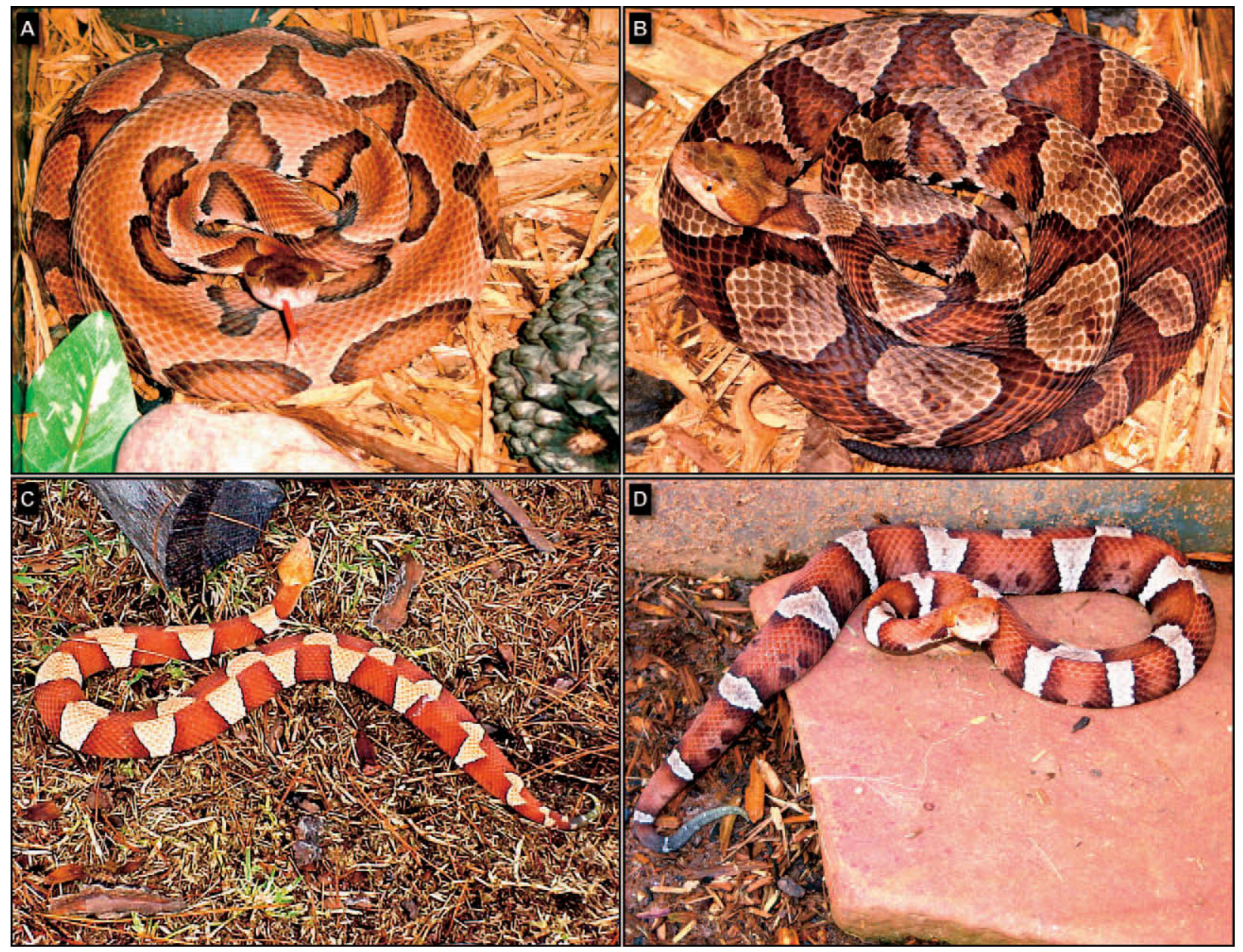

Figure 2. North American copperheads native to different regions of the hurricane strike zone. A. Southern copperhead (Agkistrodon c contortrix). B. Northern copperhead (Agkistrodon c mokasen) (Martin County, IN). C. Broad-banded copperhead (Agkistrodon c laticinctus). D. Transpecos copperhead (Agkistrodon c pictigaster) (photos by Edward Wozniak). Note the overall wider bands, the paired spots between crossbands, and the darker ground color that distinguishes the northern copperhead from the southern race. The 2 broad-banded varieties from the southwestern aspect of the hurricane strike zone look quite different from the wider ranging and more well-known northern and southern subspecies to be misidentified by uninformed individuals in the field.

labial scale edges (Figure 1D), the lack of the overall 2tone coloration, and the failure to gape and vibrate the tail are all features that may also be helpful in differentiating water snakes from cottonmouths. When undisturbed in water, cottonmouths usually swim with their whole body floating buoyantly and their head held well above the water surface..$^{15}$ In contrast to this, natricine water snakes and ribbon snakes typically swim with most of their body underwater with just their head resting on the surface. ${ }^{15}$ When threatened or disturbed, however, cottonmouths and water snakes are both capable of diving and, despite urban legends, can and will bite underwater if stepped on or otherwise restrained.

The open-mouth threat display of the cottonmouth (gaping behavior) along with the continued circulation of popular and scary fictitious urban legends concerning their perceived aggressive behavior and venom potency have resulted in the cottonmouth having an undeserved bad reputation. ${ }^{15}$ Behavioral studies have demonstrated that in most instances cottonmouths that are challenged or threatened by humans will either attempt to escape or rely heavily on threat displays and other defensive tactics. ${ }^{29}$ Only when grabbed, restrained, or stepped on will cottonmouths regularly use their fangs and venom defensively. ${ }^{29}$ Because of this and their preference for habitats that humans typically find undesirable, cottonmouths usually account for only a small percentage of the annually reported venomous snakebites in the United 


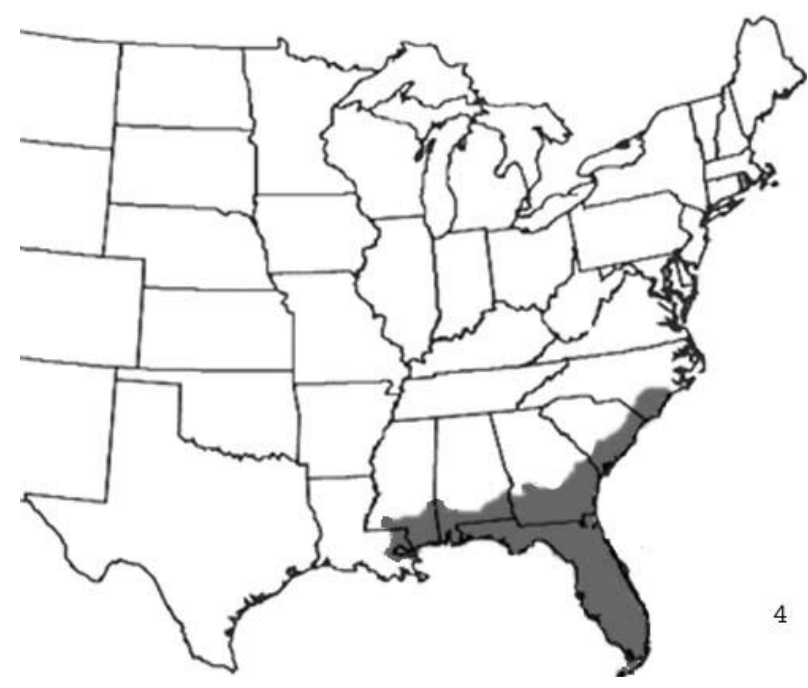

Map 4. The distribution range of the eastern diamondback rattlesnake (Crotalus adamanteus). The map represents an approximated summation of the range data from several field guides and reference books. ${ }^{12,14,17-20}$

States. ${ }^{8,9}$ In disaster-stricken areas harboring dense populations of cottonmouths, however, the incidence of bites inflicted by this species may be markedly increased. ${ }^{4}$ In flooded areas, bites to the upper half of the body have been documented in troops who had accidentally brushed into heavily foliated vegetation sticking up out of floodwater on which displaced cottonmouths had taken refuge. ${ }^{30}$ Therefore, emergency-response personnel are well advised to become familiar with the distribution, identification, biology, and behavioral characteristics of the cottonmouths.

All 3 of the cottonmouth subspecies are highly adaptable pit vipers capable of surviving in and around cities, towns, and rural residences. In some areas, cottonmouths are the most common venomous serpents to show up in towns, buildings, and other domestic areas during disasters involving floods. Cottonmouths will readily enter brackish or salt water, and dense populations of this species can be found on many of the barrier islands along the Atlantic and Gulf coasts. ${ }^{13}$ A description of each subspecies is provided below.

\section{Eastern cottonmouth}

The eastern cottonmouth (A p piscivorus) inhabits the southeastern quadrant of the United States, extending from the Great Dismal Swamp in extreme southeastern Virginia southward along the Atlantic Coast to the level of central Georgia and westward through Alabama into the northeastern corner of Mississippi. ${ }^{13}$ The eastern cottonmouth is one of the most colorful cottonmouth sub- species and is readily distinguished from the Florida race, Agkistrodon p conanti, by the lack of the dark vertical markings on the rostrum and from the western race, Agkistrodon p leucostoma, by its coloration and the presence of conspicuous dark cheek stripes on the lateral head (Figure 1A). The body profile of the eastern cottonmouth is often somewhat more triangular than the other 2 subspecies, most notably on the anterior body.

\section{Florida cottonmouth}

The Florida cottonmouth is the largest member of the $A$ piscivorus complex. The head of $A p$ conanti is conspicuously marked with vertical stripes on the rostrum and mental regions that create a distinctive "handlebar mustache-like" marking on the rostrum when viewed from the front (Figure 1B). Like their eastern cousins, Florida cottonmouths typically have prominent bilateral dark cheek stripes that are conspicuously bordered by light areas above and below. ${ }^{13}$ This pattern of head markings can be so striking that untrained people accustomed to seeing the less colorful western race sometimes have trouble identifying the Florida subspecies as a cottonmouth (E.J.W., personal observation). The Florida cottonmouth ranges from the southeastern extreme of South Carolina through coastal and southern Georgia, southward throughout the state of Florida, and westward along the Gulf Coast to the eastern face of Mobile Bay in Alabama. ${ }^{13}$

\section{Western cottonmouth}

The western cottonmouth (A p leucostoma) is the smallest but most widely distributed cottonmouth subspecies. The ground color of this subspecies can vary considerably over its extensive range and often matches the dominant soil in the region of origin. The dorsal body is patterned with 10 to 15 dark crossbands similar to the other 2 subspecies but often tends to darken at an early age (Figure 1C). The top and sides of the snout are usually uniformly dark brown to black with no visible markings except in juveniles. When visible, the upper edges of the cheek stripes usually lack the contrasting light borders that are characteristic of the Florida and eastern subspecies. ${ }^{13}$

The western cottonmouth inhabits a large portion of the southeastern to central United States, extending from Alabama and extreme western Georgia to the west and south across Mississippi, Louisiana, Arkansas, and southern Missouri and through eastern and central Oklahoma and Texas down to the level of Corpus Christi. ${ }^{13,16}$ In the western and northern fringes of its range, 


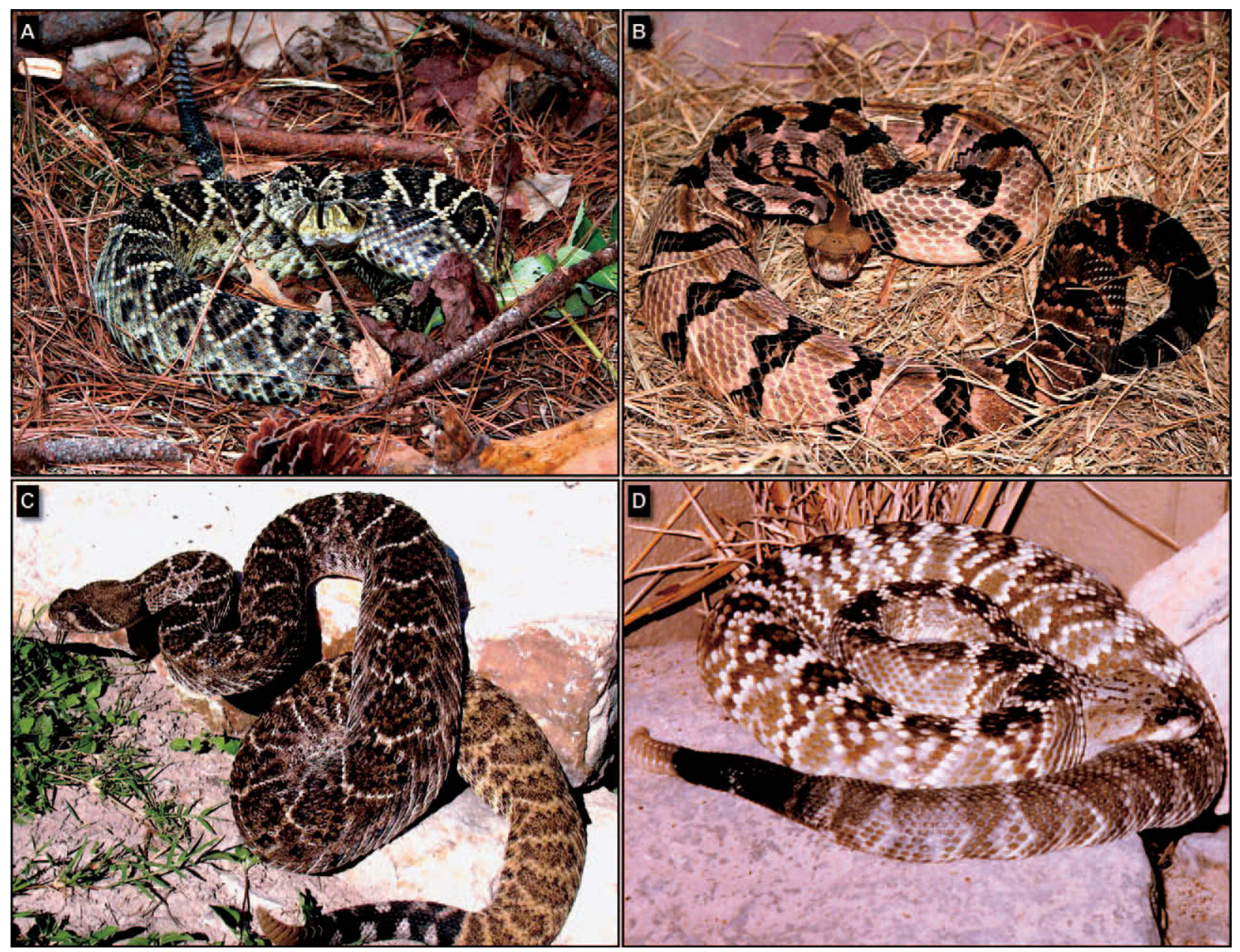

Figure 3. The 4 larger species of rattlesnakes native to the hurricane strike zone of North America. A. Eastern diamondback rattlesnake (Crotalus adamanteus) (photo by Edward Wozniak). B. Timber (canebrake) rattlesnake (Crotalus horridus) (southern Georgia) (photo by Edward Wozniak). C. Western diamondback rattlesnake (Crotalus atrox) (Travis County, TX) (photo by Michael Smith). D. Black-tailed rattlesnake (Crotalus molossus) (photo by Christina Wozniak at the Houston Zoo).

the western cottonmouth tends to exist in isolated pockets that are distributed along river systems.

\section{COPPERHEADS}

The copperhead (Agkistrodon contortrix) is a small- to medium-sized pit viper that was originally named for the coloration of its dorsal head. Five morphologically distinct subspecies are recognized, 4 of which occur in the specified geographic zone of interest. The background color of the dorsal body of all 5 subspecies is a pale copper to reddish tan. The dorsum is typically patterned with a series of prominent brown to chestnut-colored crossbands. ${ }^{13}$ The shape, number, and color details of the crossbands vary considerably across the subspecies and can lead to misidentification. The range of the copperhead is centered on the southeastern United States with extensions to the north along the eastern seaboard, westward into the eastern Great Plains, and southwestward across the Edwards Plateau and into the TransPecos region of Texas and adjacent northeastern Mexico (Maps 2 and 3).

The American copperhead is a highly adaptable pit viper capable of surviving in and around human habitations, including the wooded suburbs and parks in and around larger cities. ${ }^{15}$ Behaviorally, copperheads may be classified as an "offensive" species because, in contrast to cottonmouths, they will often strike when provoked or threatened. ${ }^{18}$ Because of their propensity to bite and their high relative abundance in many areas, copperheads are responsible for a large portion of the snake envenomation cases reported in the eastern half of North America each year. ${ }^{8,9}$ In North Carolina, for instance, copperhead bites accounted for $64 \%$ of the venomous 
snakebites reported over a 40 -year period. ${ }^{9}$ Most copperhead bites occur on the lower extremities, a fact that is probably attributable to both their superb protective coloration and behavioral characteristics. The reported severity of copperhead bites varies somewhat in different

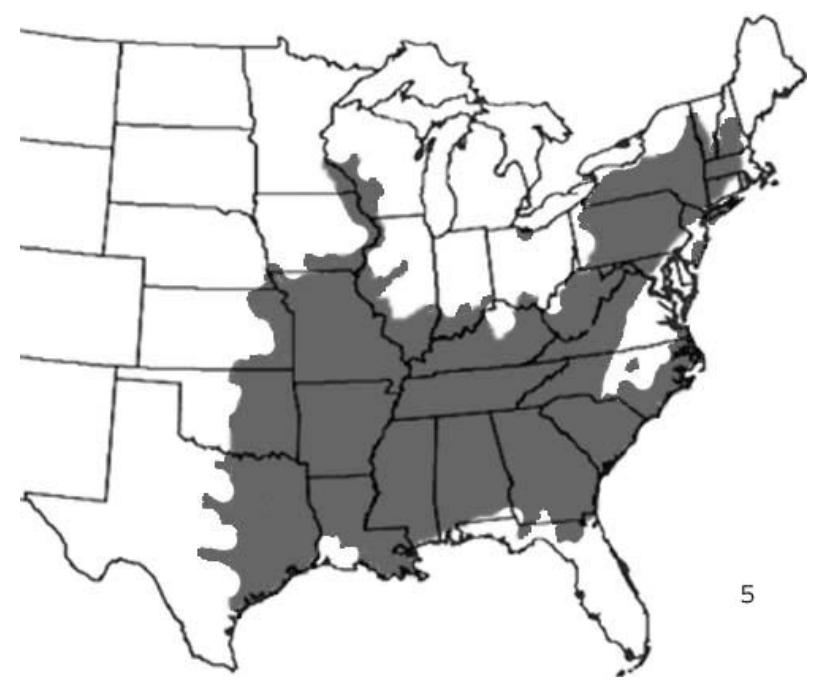

Map 5. The distribution range of the timber rattlesnake (Crotalus horridus). The map represents an approximated summation of range data for both the timber and canebrake forms of $C$ horridus and includes data from several field guides and reference books. ${ }^{12,15,16-20}$

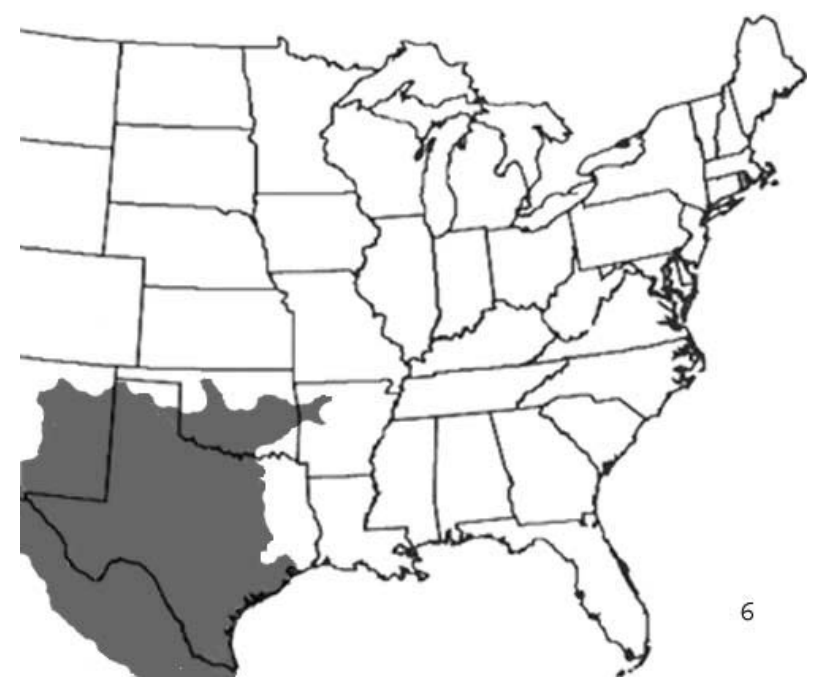

Map 6. The distribution range of the western diamondback rattlesnake (Crotalus atrox) within the hurricane-prone region of North America. The map represents an approximated summation of the range data for this species within the defined geographic region and adjacent areas and includes distribution data from several field guides and reference books. ${ }^{12,14-17,20}$ The actual range of $C$ atrox extends considerably farther to the west and south. ${ }^{17}$

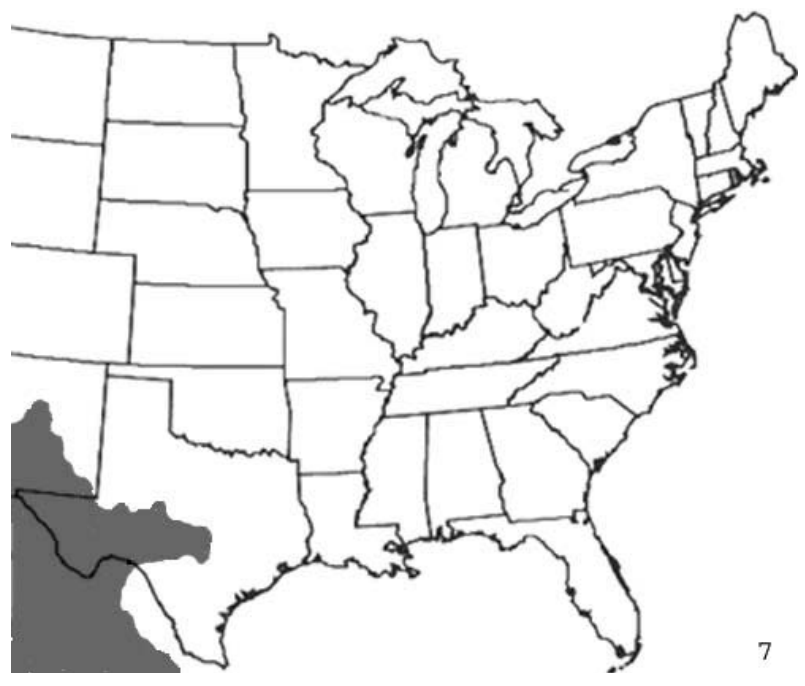

Map 7. The distribution range of the black-tailed rattlesnake (Crotalus molossus) within the hurricane-prone region of North America. The map represents an approximated summation of the range data for this species within the defined geographic region and adjacent areas and includes distribution data from several field guides and reference books. ${ }^{12,14,16,17,20}$ The actual range of $C$ molossus extends considerably farther to the west and south. Several distinct subspecies are recognized in Mexico. ${ }^{12,14,17}$

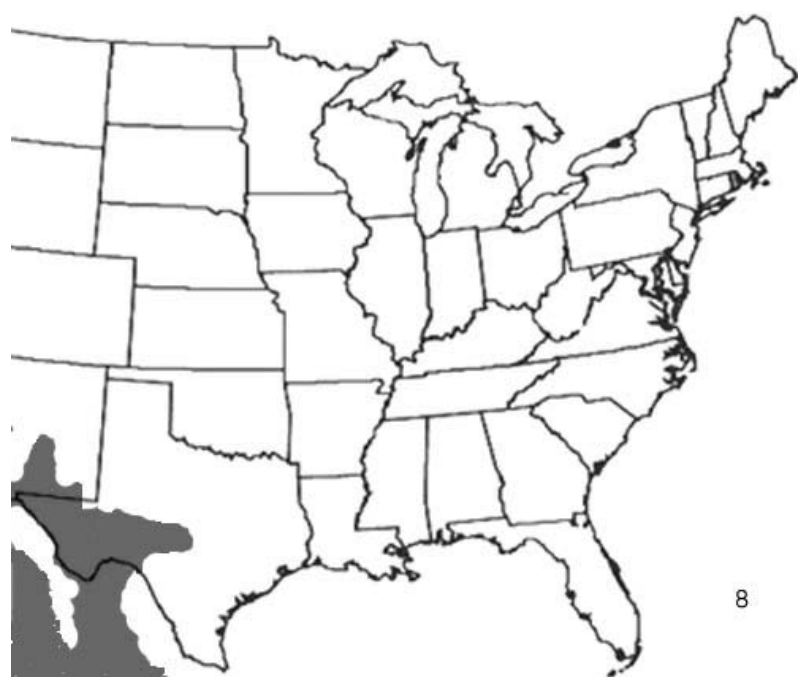

Map 8. The distribution range of the rock rattlesnake (Crotalus lepidus) within and immediately peripheral to the defined geographic region. The map represents an approximated summation of the range data for both the mottled rock rattlesnake $(C$ l lepidus) and the banded rock rattlesnake (Crotalus $l$ klauberi) and includes distribution data from several field guides and reference books. ${ }^{14,16,17,20}$ Only $C$ l lepidus ranges into the defined geographic region of concern. The actual range of the $C$ lepidus complex extends farther to the west and south. Several other distinct subspecies of $C$ lepidus are recognized in Mexico. ${ }^{12,14,17}$ 

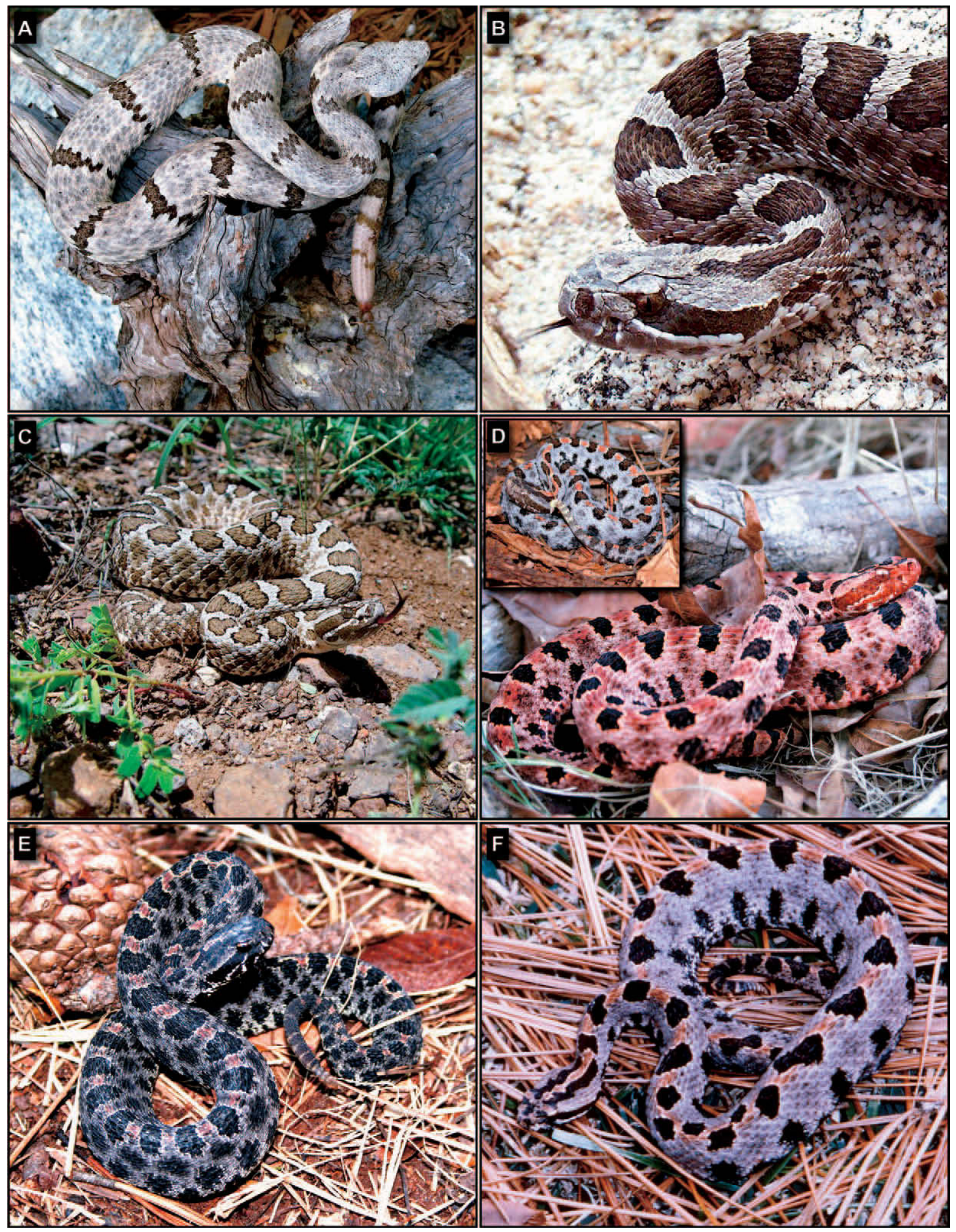


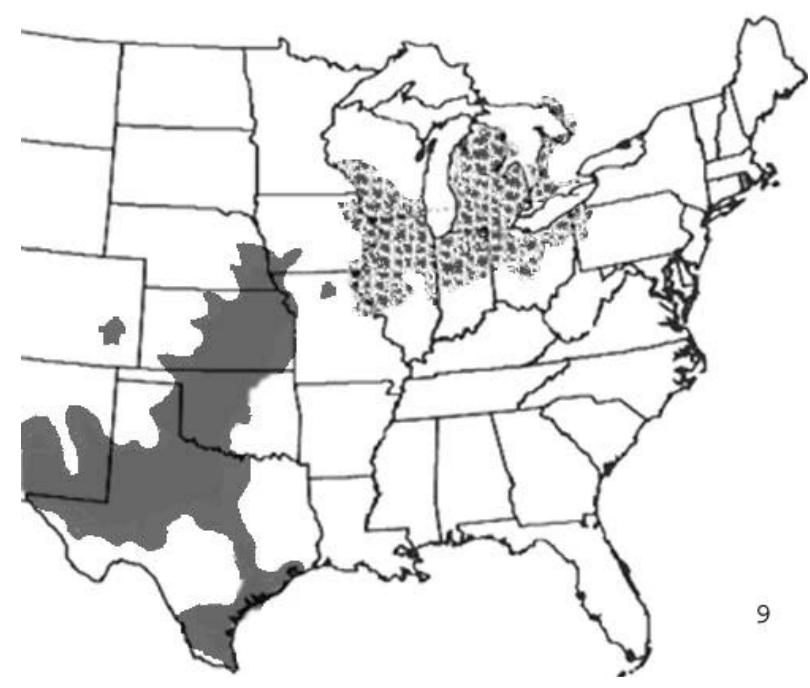

Map 9. The distribution range of the massasauga (Sistrurus catenatus) within the hurricane-prone region and adjacent areas of North America. The map represents an approximated summation of the range data for all 3 subspecies and includes distribution information from several field guides and reference books. ${ }^{12,14-17,20}$ Only the western massasauga (Sistrurus $c$ tergeminus) and the desert massasauga (Sistrurus c edwardsi) range into the defined hurricane-prone region. The eastern massasauga ( $S$ c catenatus) (textured area) is geographically isolated from the other 2 races and exists outside the defined geographic region of concern. The range of $S$ c edwardsi extends farther westward across New Mexico and into southeastern Arizona. ${ }^{14,17}$

geographic regions ${ }^{31,32}$ and may be attributable to subspecific or population-specific differences in venom potency. In many parts of their range, copperheads are known to become translocated by floodwaters and invade towns, buildings, and other domestic areas. Because of this and the marked pattern and coloration differences among subspecies, emergency-response personnel are well advised to become familiar with the distribution, biology, and identification of copperheads. A description of each subspecies that inhabits the geographic region of concern is provided under 2 distinct categories: those with hourglass-shaped crossbands and those with broad crossbands.
Copperheads with hourglass-shaped crossbands (Map 2)

Southern copperhead. A denizen of the pine and deciduous forests of the southeastern United States, the nominant race of the American copperhead, A c contortrix, is perhaps one of the best-known and widest-ranging copperhead subspecies. The southern copperhead ranges from eastern Texas and Oklahoma eastward across Louisiana, Arkansas, southern Missouri, Mississippi, and the southern two thirds of Alabama and Georgia. ${ }^{13}$ Within the central aspect of its range, the southern copperhead extends from the Mississippi River valley to the level of southern Illinois. ${ }^{13}$ Along the Atlantic Coastal Plain the southern copperhead ranges from extreme southern Delaware southward into the Florida panhandle. ${ }^{13}$ Within the state of Florida, its distribution is limited to a small region of the panhandle in and around the Apalachicola River basin and has been documented from only Gadsen, Liberty, and Calhoun counties. ${ }^{19}$ Reports of copperheads elsewhere in Florida are usually attributable to sightings of lightly pigmented cottonmouths or reddish nonvenomous species such as corn snakes (Pantherophis [= Elaphe] gutatta) that are misidentified. In eastern Texas, southern copperheads are the most common venomous snakes found in and around cities, most notably Houston. ${ }^{16}$

The dorsal body of the southern copperhead is patterned with 10 to 18 dark crossbands that are markedly constricted at the dorsal midline (Figure 2A). Crossband width at the dorsal apex is typically 3 scale rows or less. ${ }^{13}$ Incomplete crossbands, the apices of which fail to meet at the dorsal midline, are common, most notably on the caudal half of the body. ${ }^{13}$ Unlike on its broadbanded and northern cousins, the bases of the crossbands do not extend onto the first scale rows of the lateral body. ${ }^{13}$ The dark spots between crossbands in the dorsal pattern that are typical of the northern copperhead are completely lacking on "pure" A c contortrix..$^{13}$ The ventrum of this subspecies is diffusely pale except for a series of round to ovoid dark ventrolateral spots corresponding to the areas between crossbands that alternate

$\leftarrow$

Figure 4. Illustrations of the 6 smaller species and subspecies of rattlesnakes native to the hurricane strike zone of North America. A. Mottled rock rattlesnake (Crotalus l lepidus) (Edwards County, TX) (photo by Edward Wozniak). B. Western massasauga (Sistrurus c tergeminus) (photo by Michael Smith). C. Desert massasauga (Sistrurus c edwardsi) (photo by Joe Forks). D. Red color phase of the Carolina pygmy rattlesnake (Sistrurus $m$ miliarius) and a juvenile specimen of the silver color phase with a yellow tail (inset; inset photo by John Willson at the Savannah River Ecology Laboratory). Juvenile cottonmouths, copperheads, pygmy rattlesnakes, and massasaugas often have yellow tails, which are used as "lures" for small insectivorous frogs and lizards. E. Dusky pygmy rattlesnake (Sistrurus $m$ barbouri) (photo by Edward Wozniak). F. Western pygmy rattlesnake (Sistrurus $m$ streckeri) (photo by Edward Wozniak). 


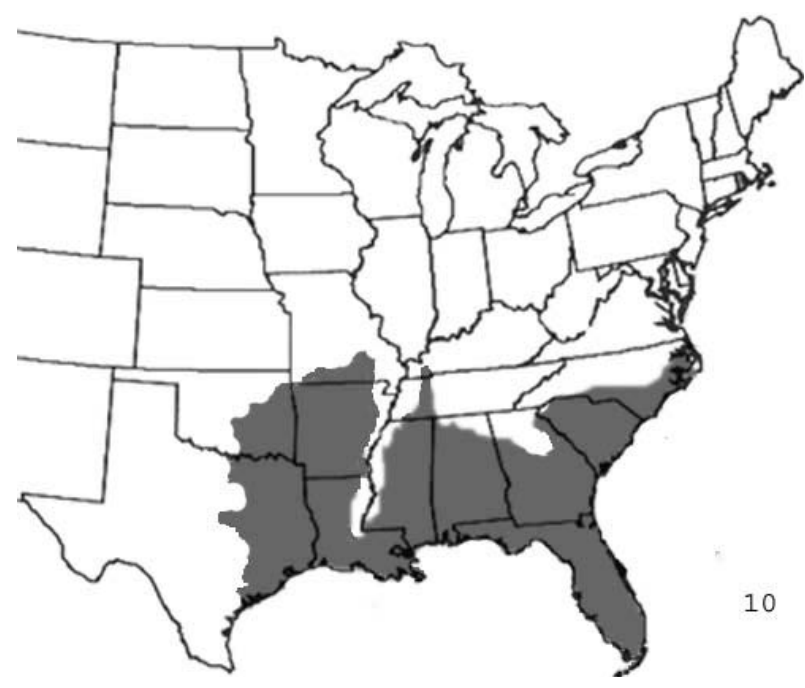

Map 10. The distribution range of the North American pygmy rattlesnake (Sistrurus miliaris). The map includes all 3 of the currently recognized pygmy rattlesnake subspecies: the Carolina pygmy rattlesnake ( $\mathrm{m}$ miliaris), the dusky pygmy rattlesnake (Sistrurus $m$ barbouri), and the western pygmy rattlesnake (Sistrurus $m$ streckeri). The shaded area represents an approximated summation of data from several field guides and reference books. ${ }^{12,15-20}$

with lighter, slightly more ventral spots situated beneath the center of each crossband. ${ }^{13}$

The southern copperhead is largely characterized as a terrestrial woodland snake that is also known to inhabit swamps, bottomlands, river valleys, and rocky ledges. ${ }^{15,19}$ It is seldom found in the coastal salt marsh regions and, unlike its cousin the cottonmouth, has not extensively populated the barrier islands along the Atlantic and Gulf coasts. ${ }^{19}$ The southern copperhead readily intergrades with other copperhead subspecies. Intergradation with the northern copperhead is particularly widespread and apparent along a large portion of the eastern seaboard extending from southern Maryland across the Carolinas to the level of east-central Georgia. ${ }^{13}$

Northern copperhead. The Northern copperhead, Agkistrodon c mokasen, is the largest and darkest copperhead subspecies. The ground color of this subspecies is generally brown to gray and is often likened to the color of a tarnished penny (Figure 2B). The dorsal body typically bears a pattern of 12 to 21 dumbbell-shaped chestnut-colored crossbands that extend all the way down to the first scale row on the lateral body. ${ }^{13}$ The apices of the crossbands are generally wider (3-5 scales wide) and the frequency of incomplete crossbands is much lower than in the southern subspecies. ${ }^{13} \mathrm{~A}$ conspicuous pattern of bilateral dark spots is typically present between the

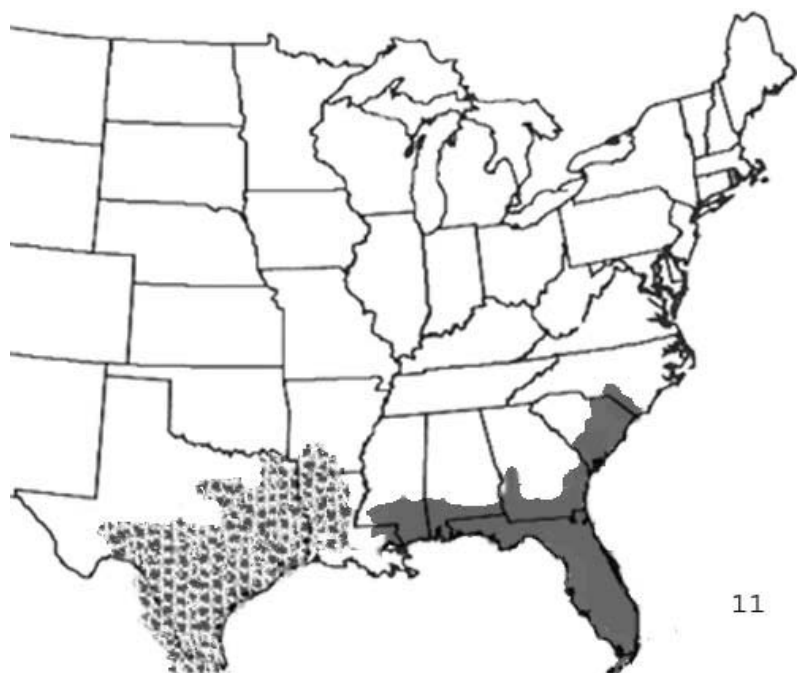

Map 11. The distribution range of coral snakes native to the hurricane-prone region of North America. The map represents an approximated summation of range data for the eastern coral snake (Micrurus fulvius) (solid gray area) and the Texas coral snake (Micrurus tener) (textured area). ${ }^{15-20}$ The range of $M$ tener continues southward across the border into Mexico. ${ }^{17}$

crossbands on the dorsal body. ${ }^{13}$ The fine dark stippling usually present in both the crossbands and ground color reduces the contrast between the crossbands and ground color in some individuals. The northern copperhead ranges from extreme northeastern Mississippi, northern Alabama, and Georgia to the north and northeast across southern Illinois, Indiana, Ohio, and Pennsylvania and throughout the Appalachian Mountains to the level of southeastern New York and southern Massachusetts. ${ }^{13}$ The preferred habitat of the northern copperhead is open deciduous forests and rocky areas with an abundance of fallen leaves. ${ }^{20}$

\section{Copperheads with broad crossbands (Map 3)}

Broad-banded copperhead. The broad-banded copperhead (Agkistrodon c laticinctus) is a south-central copperhead subspecies and one of the most strikingly colorful. The dorsal body typically bears a pattern of 10 to 17 broad chestnut-colored to reddish orange crossbands that sharply contrast a light orange to tan background (Figure 2C). The crossbands of this race are typically 6 to 8 scales wide at the dorsal apex and 8 to 12 scales wide at their lateral base. ${ }^{13}$ Unlike on most of the other copperheads, the crossbands of this subspecies extend down onto the ventral scutes. ${ }^{13}$ This pattern gives many broad-banded copperheads an alternating coppery red color that is quite different from the more well-known northern and southern subspecies. 




Figure 5. A coral snake and a harmless mimic. A. Texas coral snake (Micrurus tener) (Galveston County, TX). The eastern coral snake (Micrurus fulvius fulvius) is very similar in appearance and differs primarily in the distribution of black mottling within the red segments. B. The harmless Mexican milk snake (Lampropeltis triangulum annulata). Note the difference in the sequence of colored bands between these 2 species. (Photos by Edward Wozniak.)

The broad-banded copperhead ranges throughout south-central Texas to the level of Victoria and Frio counties northward through central Oklahoma up to the level of Cowley County, KS. ${ }^{13}$ Unlike their northern and southern cousins, which are frequently found in association with rocks and talus slopes, the broad-banded copperhead has a distinct preference for areas with sandy soil that are covered with live oak trees and brush. ${ }^{13,14}$ Within such regions, the underlying dead leaf litter provides nearly perfect camouflage for the snake's sharply contrasting pattern and coloration.

Transpecos copperhead. The transpecos copperhead (Agkistrodon c pictigaster) is the southwestern-most copperhead subspecies and is the only copperhead that ranges across the Rio Grande into Mexico. ${ }^{13,17}$ The transpecos copperhead is patterned with 10 to 18 broad reddish brown to chestnut-colored crossbands that are nearly as wide at the dorsal apex as they are at the base (Figure 2D). The ventrolateral base of each crossband typically bears a conspicuous pale inverted U-shaped marking that highlights a dark central spot. As on the broad-banded copperhead, the crossbands extend ventrally onto the scutes where the cranial and caudal margins and the central dark spots form a series of 3 conspicuous dark brown to black markings on the ventrum (triads). ${ }^{13}$ The ventral triads and the presence of pale inverted U-shaped markings in the ventral margin of each crossband are readily apparent features that distinguish the transpecos copperhead from its broad-banded cousin, A c laticinctus. ${ }^{13}$

The transpecos copperhead exists in relict populations in the riparian woodlands, forested canyons, canebrakes, and scrubby flatlands scattered throughout the Chihuahuan Biotic Province of southwestern Texas and adjacent north-central Mexico and is therefore present only in the southwestern extreme of the area of concern. ${ }^{13,16}$ The preference of the transpecos copperhead for living along rivers makes it particularly vulnerable to being translocated by rapidly rising floodwater. ${ }^{13}$ Dense populations of this copperhead can be found in or around piles of dead cane that accumulate on fence rows close to rivers traversing areas with a history of flooding. ${ }^{13,15}$ Historically, this region of Texas has proven to be highly susceptible to rapidly rising hurricane-associated floods. ${ }^{6}$ Although it is one of the smaller copperhead subspecies, the transpecos copperhead is an excitable and easily agitated snake that is quick to deliver a venomous bite if disturbed.

\section{RATTLESNAKES}

The rattlesnakes are a well-known group of pit vipers unique to the New World. All but 1 insular form (Crotalus catalinensis) have a conspicuous rattle on the distal tail that is composed of loosely attached interlocking buttons of horny keratin. Under normal conditions, the collision between the narrowly separated inner and outer layers of horny keratin comprising the rattle is responsible for the production of the familiar buzzing sound that is produced when the snake shakes the structure at a high rate of speed. ${ }^{12}$ It should be noted, however, that the entry of water into the rattle can both soften keratin and dampen the collision between the opposing layers, effectively silencing even the loudest of specimens. Rat- 
tles softened by prolonged submersion in water often become fragile and may break off. Because of these factors and the fact that under many circumstances rattlesnakes will "bite first and rattle later," one should never rely on the common misconception that rattlesnakes will always sound a warning before delivering a bite, especially under damp or flooded conditions.

Two distinct genera of rattlesnakes are recognized: Crotalus, which includes all the larger varieties, and Sistrurus, the massasaugas and pygmy rattlesnakes. ${ }^{12,14,17}$ Generic classification is largely based upon the morphology of the scales covering the crown of the head. The crown of Crotalus species is covered with small scales. ${ }^{14}$ In direct contrast to this, the crown of Sistrurus spp is covered with 9 large plates similar to those observed on copperheads and cottonmouths. ${ }^{14}$ Seven distinct species of rattlesnakes inhabit the hurricane-prone region of North America. A description of each species and subspecies is provided below.

\section{Eastern diamondback rattlesnake}

The eastern diamondback rattlesnake (Crotalus adamanteus) is a large gray to olive serpent that ranges across the southeastern United States from the coastal lowlands of southeastern North Carolina southward to the level of the Florida Keys and westward along the Gulf Coast to extreme southeastern Louisiana (Map 4). The dorsal pattern of the eastern diamondback consists of a series of prominent white to yellow-edged chocolate to black diamond-shaped markings with light centers that fade into pale crossbands on the caudal aspect of the body (Figure 3A). The tail of this species is often slightly darker than the ground color and typically bears a series of inconspicuous black rings. ${ }^{19}$ The head is distinctly marked with a dark mask bordered by sharply contrasting white lines that run diagonally across the cheeks. It is the only rattlesnake within its range that has a "facial mask" bordered by white lines. ${ }^{20}$

$C$ adamanteus holds the world record as the largest rattlesnake species. Although the average diamondback found today is 32 to 48 inches long, individuals well over 6 feet long have been recorded. The largest specimen on record measured an astounding 8 feet in length and had a midbody diameter of 4.5 inches. ${ }^{20}$ Eastern diamondbacks have long fangs and large venom glands and produce copious amounts of potent venom with hemotoxic, necrotizing, and neurotoxic effects. ${ }^{8,20}$ As with other pit vipers, venom potency can vary somewhat among different populations. In the experience of 2 of the authors (J.W. and E.J.W.), specimens from certain localities in southern Georgia have particularly potent venom that consistently produces ominous signs of neurotoxicity in rodents.

The eastern diamondback inhabits the palmetto scrub areas and flatwoods, longleaf pine forests, live oak forests, sand hills, and coastal marine hammocks throughout its range where it frequently resides in gopher tortoise burrows, in stump holes, and under debris. ${ }^{20} C$ adamanteus readily enters salt water and swims to islands as far from the mainland as the Florida Keys and is common on many of the coastal islands in southern Georgia. $^{20}$

\section{Timber rattlesnake}

The timber rattlesnake (Crotalus horridus) is a large, heavy-bodied, banded rattlesnake that ranges throughout a large portion of eastern and central North America from eastern Texas, Oklahoma, and Kansas across most of the south-central and southeastern United States to the level of northern (Alachua County) Florida and throughout the Appalachian Mountains to southern Maine ${ }^{13}$ (Map 5). The ground color of this species varies somewhat across its geographic range but is generally yellow to tan with variable amounts of black stippling. ${ }^{20}$ The dorsal pattern is best characterized as a series of black chevrons, and the caudal body and tail are almost invariably black, a feature that gives the species the local name "velvet-tailed rattler" in some localities (Figure 3B). Individuals originating from the southern and western aspects of the range often have a prominent cinnamon-colored vertebral stripe that extends from the neck down to the level of the tail. ${ }^{15,19}$ The head is typically plain in individuals from the Northeast but often bears a black stripe that extends from the eyes caudoventrally to and beyond the corners of the mouth on individuals from the southern and western aspects of the range. ${ }^{19}$ The opinion as to whether the southern form represents a distinct subspecies (canebrake rattlesnake) is divided among many herpetologists.

The timber rattlesnake inhabits a variety of habitats including but not limited to upland deciduous forests, rocky ridges, riparian corridors, cypress swamps, cane reed thickets, and wet prairie regions. $C$ horridus is a large rattlesnake species that produces moderate to large amounts of potent venom. Certain populations of this species have been shown to produce deadly neurotoxic peptides. ${ }^{19}$ Both of the snakebite fatalities reported to the American Association of Poison Control Centers in 2002 were attributable to bites by $C$ horridus.

\section{Western diamondback rattlesnake}

The western diamondback rattlesnake (Crotalus atrox) is a large gray to rust-colored serpent that is widely dis- 
tributed across the southwestern to south-central regions of the United States and adjacent Mexico (Map 6). The dorsum of the typical $C$ atrox bears a series of dark rhomboid-shaped markings that are bordered by concentric rows of sharply contrasting dark and light cream to white scales (Figure 3C). The dorsal pattern is most prominent on the anterior half of the body and fades into a series of pale crossbands caudally. The tail of this species is conspicuously marked with a series of contrasting black and white rings of roughly equivalent width, a feature that has earned the species the local name "coontailed rattlesnake" in some localities. ${ }^{20}$ The head of the western diamondback bears a dark gray mask bordered by prominent white lines that run diagonally across the cheeks, effectively concealing the eyes. Unlike on any other rattlesnake in its range, the caudal white lines of the mask run down to rather than behind the corners of the mouth on both sides of the head. ${ }^{15}$

Throughout its range, which extends from southeastern California through the lower elevation regions of Arizona, New Mexico, and a large portion of Texas and Oklahoma, the western diamondback thrives in a variety of habitats, including deserts, prairies, thorn forests, and woodlands. ${ }^{15} \mathrm{C}$ atrox is an abundant species along approximately $80 \%$ of the Texas Gulf Coast and its barrier islands from Galveston Island southwestward to and beyond the level of Brownsville. Inland, the western diamondback is also abundant throughout the south Texas brush country. ${ }^{15}$ The average adult size attained by $C$ atrox varies considerably across the snake's extensive range. Over most of their range, adult western diamondbacks average 3 to 4 feet in length. In the Starr, Willacy, and Hidalgo counties in south Texas, however, western diamondbacks over 5 feet in length are not uncommon. ${ }^{15}$ The western diamondback is characterized as a highly excitable and aggressive rattlesnake species that is responsible for a significant portion of the venomous snakebites reported in the United States each year. ${ }^{8,10}$

\section{Black-tailed rattlesnake}

The northern black-tailed rattlesnake (Crotalus $m$ molossus) is a medium- to large-sized rattlesnake that ranges throughout portions of southern and central Arizona, southern New Mexico, southwestern Texas, and adjacent Mexico (Map 7). The ground color of this species varies predictably across its US distribution, ranging from light gray (Texas) to yellowish green (Arizona). The dorsal pattern of the black-tailed rattlesnake consists of a series of black diamond-shaped blotches with light centers (Figure 3D). Posterior to the neck region, the lateral points of each diamond typically extend ventrally to the level of the first scale row, effectively forming a series of distinctive crossbands. On the posterior two thirds of the body, the markings are reduced to light centered crossbands. The tail of this species is typically solid black; however, unlike on the timber rattlesnake, the black coloration does not extend anterior to the vent. The head of $C m$ molossus typically bears a prominent solid black stripe that extends diagonally across the cheeks from just above the corners of the mouth upward to and across the anterior crown, creating a masklike marking that effectively conceals the eyes. ${ }^{15}$

C $m$ molossus inhabits the wooded canyons, cliffs, and rock piles in the west-central Edwards Plateau and the adjacent Chihuahuan Desert and is therefore present only in the southwestern extreme of the hurricane-prone region of North America. ${ }^{15}$ Although typically a mild-tempered rattlesnake, $C m$ molossus packs moderate to large amounts of potent venom and is unquestionably a dangerous species. ${ }^{26,27,33,34}$

\section{Mottled rock rattlesnake}

The mottled rock rattlesnake (Crotalus $l$ lepidus) is a small, banded rattlesnake species that, along with the transpecos copperhead and black-tailed rattlesnake, is found only in the extreme southwestern quadrant of the hurricane-prone area of North America (Map 8). The mottled rock rattlesnake is easily recognized by its bluish gray to pink background and its pattern of black jagged-edged crossbands that start out pale on the neck and become increasingly darker and more prominent posteriorly (Figure 4A). The ground color and degree of black mottling varies considerably over the snake's range and typically matches the rocks in the locality from which the snake originated. ${ }^{15}$ The tail of this species is typically tan and bears a series of several thin widely spaced black rings. The head of the mottled rock rattlesnake bears a pair of dark diagonal cheek stripes that extend from the back of each eye to an area just posterior to the corners of the mouth. ${ }^{15}$

Rock rattlesnakes inhabit the limestone canyons, rock outcroppings, bluffs, and mountain woodlands throughout the Trans-Pecos region of Texas and a small portion of southeastern New Mexico and southward through an extensive area of adjacent Mexico. ${ }^{15-17}$ C lepidus is generally considered to be a reclusive but excitable rattlesnake species. Certain populations of this species have been documented to produce a potent neurotoxic peptide similar to that produced by the Mohave rattlesnake (Crotalus scutulatus scutulatus). ${ }^{35}$

\section{Massasaugas}

The massasaugas (Sistrurus catenatus) are a group of small rattlesnakes that exist as a complex of 3 distinct 
subspecies, 2 of which range into the geographic region of concern (Map 9). All 3 subspecies are superficially similar in appearance and can be distinguished in the field only by subtle details in the pattern and coloration. ${ }^{14}$ Because massasaugas are members of the genus Sistrurus, the crown of the head is covered with 9 large plates similar to those on pygmy rattlesnakes, copperheads, and cottonmouths.

The massasaugas range diagonally across the prairie region of the central United States, extending from Canada and adjacent Lower Peninsula of Michigan across the Midwest down through southern and southwestern Texas, New Mexico, and southeastern Arizona and into adjacent Mexico (Map 9). Once an abundant species in many areas, massasaugas have become uncommon animals over much of their range and are now protected in several states. Massasaugas produce moderately potent venom and, despite their small size, are capable of administering a serious bite.

Western massasauga. The western massasauga (Sistrurus $c$ tergeminus) is a small- to medium-sized blotched rattlesnake that ranges throughout a large portion of the southwestern prairie region of the United States. Their ground color is typically gray to tan, and the dorsum typically bears a series of round to irregularly shaped dark blotches (Figure 4B). The sides of the head are marked with a dark, white-edged mask that runs diagonally across the cheeks, extending from the crown to an area just posterior to the corners of the mouth. ${ }^{17,20}$ The ventral scales of this subspecies are mottled with gray pigment. ${ }^{20}$

The western massasauga is spottily distributed throughout the Great Plains, including the tallgrass prairie along the central Gulf Coast in Texas. ${ }^{15}$ Within the hurricane strike zone of North America, it is known only from a small region of the Texas Gulf Coast near the city of Palacios and the adjacent inland area extending northwestward toward the Texas panhandle. ${ }^{16}$

Desert massasauga. The desert massasauga (Sistrurus c edwardsi) is the smallest massasauga subspecies and is distinguished from its western cousin only by its slightly lighter ground color, fewer dorsal blotches, and the lack of gray mottling on the ventral scutes (Figure $4 \mathrm{C}$ ). The ground color of this subspecies is typically tan to light gray, and the blotches comprising the dorsal pattern are often more widely spaced than on its western cousin, $S$ c tergeminus. Along the south Texas Gulf Coast, the desert massasauga ranges from the city of Palacios southward along the coast and its barrier islands and westward throughout most of the south Texas brush country. ${ }^{15,16}$ The name "desert massasauga" is actually misleading because this species inhabits primarily dry short-grass prairie, mesquite or prickly pear savanna, and grass-covered sand dune areas throughout much of its range..$^{15}$

\section{Pygmy rattlesnakes}

The pygmy rattlesnakes (Sistrurus miliarius) are a group of small rattlesnakes that range throughout a large portion of the southeastern United States (Map 10). The ground color of the pygmy rattlesnakes varies from light gray to brown to red, and the dorsum typically bears a pattern of prominent round to ovoid silver-edged blotches that are flanked by 1 to 2 rows of smaller round spots on both sides of the body (Figure 4D-F). A rust-colored middorsal stripe is often present on the anterior half of the body but may be lacking in some individuals or obscured by blending with the ground color on reddish specimens. ${ }^{20}$ Unlike any other rattlesnake species, the rattle of $S$ miliarius is tiny and inconspicuous and is capable of producing a buzzing sound that is at best audible from only a few feet away (Figure 4E and F).

Pygmy rattlesnakes are agile and quick-moving rattlesnakes. When disturbed, they typically flatten their bodies and snap sharply sideways without coiling and raising their forebody like some of the larger crotalids. ${ }^{19}$ Because of this and their small size, the strike range of the pygmy rattlesnakes seldom exceeds a few inches. The temperament of this species is reported to vary considerably among individuals and under different conditions. ${ }^{14}$ The venom is characterized as moderately potent but is available only in small quantities. Nevertheless, pygmy rattlesnake bites are a serious matter and are worthy of prompt medical attention. Three distinct subspecies are recognized.

Carolina pygmy rattlesnake. The Carolina pygmy rattlesnake ( $S \mathrm{~m}$ miliarius) is the most distinctly patterned and brightly colored subspecies of the group (Figure 4D and inset). $S m$ miliarius ranges from eastern North Carolina southwestward through most of South Carolina, across central Georgia and Alabama, and into a small portion of east-central Mississippi. ${ }^{20}$ Throughout its range, the Carolina pygmy rattlesnake is a forest-dwelling species that inhabits the long-needle pine-scrub oak and pine flatwood areas along the Atlantic Coastal Plain and the pine-oak forests in the western aspect of its range. ${ }^{20}$ The ground color of this subspecies is highly variable and typically matches the dominant soil color in the locality from which the snake originated (Figure $4 \mathrm{D}$ and inset). Individuals originating from central North Carolina, certain areas in South Carolina, and northeastern Georgia often have an overall red or pinkish orange ground color (Figure 4D).

Dusky pygmy rattlesnake. The dusky pygmy rattlesnake (Sistrurus $m$ barbouri) is the southern counterpart 
of the Carolina pygmy rattlesnake and ranges from southern South Carolina westward across southern Alabama, southward throughout the state of Florida, and westward into southeastern Mississippi. ${ }^{20}$ The dusky pygmy rattlesnake superficially resembles the Carolina subspecies but typically has a "dusted" appearance because of the diffuse black mottling in the ground color (Figure 4E). Anerythristic individuals lacking the red middorsal stripe are common in certain populations. Throughout its range, the dusky pygmy rattlesnake inhabits the pine flatwoods, moist prairies, and virtually any type of other habitat that offers sufficient cover and is close to water. ${ }^{19}$ Dense populations of this little rattlesnake can be found in many areas of Florida, especially in the moist prairies around the everglades. ${ }^{19}$ With flooding, dusky pygmy rattlesnakes frequently show up in towns and will readily invade buildings.

Western pygmy rattlesnake. The western pygmy rattlesnake (Sistrurus $m$ streckeri) ranges throughout most of Mississippi, Arkansas, and Louisiana and into eastern Texas and southeastern Oklahoma and is therefore the most widely distributed pygmy rattlesnake subspecies. ${ }^{20}$ Although it is a wide-ranging animal, $S m$ streckeri is spottily distributed over its range and is a rather uncommon snake in many areas, most notably in the state of Texas. ${ }^{16}$ The ground color of this subspecies is typically light pink to tan. Unlike the other 2 pygmy rattlesnake subspecies, the dorsal blotches of the western pygmy rattlesnake are often laterally extended and appear as transverse barlike spots (Figure 4F). The preferred habitat of this subspecies is similar to that described for the Carolina pygmy rattlesnake.

\section{Pit viper venoms and their effects}

Viperid snake venom is a yellow to whitish liquid that contains a complex mixture of tissue-destructive enzymes, toxic peptides, and other factors with potent proinflammatory, hemotoxic, and necrotizing effects. ${ }^{8}$ Because of the potential depth of injection afforded by the long fangs, viper venoms often spread by both lymphatic and hematogenous routes, leaving a telltale trail of swelling, discoloration, and sensitivity they diffuse from the initial site of the bite. ${ }^{10}$ Generally, the gravity of a viperid snakebite is proportional to both the depth of the bite and the amount of venom injected, both of which are typically greater with larger specimens. Severe local pain and swelling, high compartmental pressures, myonecrosis, coagulopathy, hemorrhage, bulla formation, cardiac toxicity, shock, and multiorgan system failure are all possible with viperid bites. ${ }^{8,10} \mathrm{Co}-$ agulopathy can be prolonged and may recur in cases successfully reversed by antivenom therapy. ${ }^{36}$ Disfigure- ment and long-term limb dysfunction are common sequelae. ${ }^{31,32,34,37}$

Several species of North American rattlesnakes have recently been documented to produce venoms that contain deadly neurotoxic peptides, most notably certain populations of the Mohave rattlesnake (Type-A C scutulatus scutulatus), the northern and southern Pacific rattlesnakes (Crotalus oreganus), the eastern diamondback rattlesnake ( $C$ adamanteus), the timber rattlesnake ( $C$ horridus), and the rock rattlesnake (C lepidus). ${ }^{8,15,35,38,39}$ Muscle fasciculation, numbness around the mouth, visual disturbances, and respiratory paralysis have been reported with bites of some of these species. ${ }^{14}$ Recent studies suggest that the evolution of such factors may be related to the development of venom resistance in preyanimal species. ${ }^{40}$ With bites from some of these "neurotoxic" variants, most notably the Type-A Mohave rattlesnake, the local signs of the typical rattlesnake envenomation may be minimal, leading the uninformed victim and sometimes health care personnel to severely underestimate the seriousness of the bite.

Because of species-, subspecies-, and in some cases locality-specific differences in venom pharmacology, accurate identification of the snake involved in a bite case can be an important piece of information for the attending physician caring for snakebite victims and can be valuable in both monitoring a patient and formulating an effective treatment plan. 8,38 With bites inflicted by exotic species, accurate identification is critical to proper antivenom selection. ${ }^{8}$ Lastly, accurate identification protects people bitten by nonvenomous snakes from the risk of undergoing unnecessary antivenom therapy. Because of these and other factors, accurate identification of the snake involved in a bite can be an invaluable component of a patient's care. ${ }^{8,38,40}$ Taking a digital picture of a snake involved in a bite case from a safe distance and sending the image to the attending physician and other officials may be the safest and easiest way of rapidly securing and documenting identification.

\section{First aid for pit viper bite}

Studies on pit viper envenomations and their outcomes have led to numerous changes in the recommended firstaid measures. The old "cut and suck" method recommended in the 1960s and 1970s and the use of venomextraction devices, chill methods, electroshock therapy, and tourniquets have all been shown to potentially worsen the outcome of a bite and are now strongly discouraged. ${ }^{9,10}$

It is currently recommended that victims of pit viper envenomation be placed at rest and kept calm and warm. ${ }^{8,10}$ The injured part of the body should be freed 
of any constricting jewelry; immobilized with a loosefitting dressing; and, if possible, maintained at the level of the heart. ${ }^{10}$ Paramedical attention should be directed toward the maintenance of a patent airway, administration of oxygen, establishment of intravenous access in an unaffected limb, and prompt transportation to the nearest medical facility. ${ }^{10}$ Immediate hypersensitivity to venom components is possible in some victims and may require the use of epinephrine and antihistamines to lesson its impact. ${ }^{8}$ The progression of swelling should be closely monitored during transport. Marking the advancing edge of the swelling with a marker at 15- to 20minute intervals can provide the treating physician with valuable information on gauging the bite's severity.

Once at a medical facility, all victims of snakebite should be promptly evaluated. Aggressive supportive care including pain management, wound care, updating tetanus prophylaxis, and sometimes antivenom therapy are often required with cases involving moderate to severe envenomation. ${ }^{10}$ The decision to administer antivenom should be made on a case-by-case basis and only by a qualified physician. Factors considered in this decision should include the snake species involved in the incident, the progression of local effects, signs of systemic poisoning, laboratory findings, and the victim's hypersensitivity status. The only antivenom approved by the Food and Drug Administration for North American crotalid bites that is currently being manufactured is CroFab (Protherics-Altana division of Savage Laboratories, Melville, NY). CroFab is a polyvalent, ovinederived Fab product that is prepared against the venoms of 4 North American pit vipers: the western diamondback rattlesnake ( $C$ atrox), the eastern diamondback rattlesnake ( $C$ adamanteus), the Mohave rattlesnake $(C$ scutulatus), and the cottonmouth (A piscivorus). ${ }^{34} \mathrm{Ex}-$ perimental studies and clinical case reports have shown this antivenom product to have activity against the venoms of a wide range of New World pit vipers. ${ }^{25,26,28,33,34}$ Although uncommon, adverse reactions including immediate hypersensitivity reactions and serum sickness are still possible with Fab-based antitoxin products and need to be considered and monitored for in-patients treated with CroFab. ${ }^{41-43}$ Consultation with a medical toxicologist at a regional poison control center (National Hotline (800)222-1222) is recommended for the treatment of any pit viper envenomation cases.

\section{Coral snakes}

Coral snakes are small brightly colored members of the family Elapidae and represent the only members of this family that are native to North America. Two species of coral snakes inhabit the geographic region of interest: the eastern coral snake (Micrurus fulvius) and the Texas coral snake (Micrurus tener) (Map 11). Both species have the characteristic pattern of wide red and black rings that are separated by thinner yellow rings and can readily be distinguished from the similarly colored harmless king, milk, and scarlet snakes by the infamous rhyme, "red on yellow kill a fellow" (Figure 5). Although species from outside the boundaries of North America are beyond the scope of this study, it should be noted that this color rule does not apply to many of the medically important coral snake species that inhabit Mexico and Central and South America. ${ }^{17}$

Coral snakes are characterized as secretive and inoffensive animals that are largely fossorial and seldom seen, even in areas that harbor dense populations. Unlike the viperids, coral snakes are typically diurnal and are most often encountered in the morning. ${ }^{15,19}$ Coral snakes are known to live in and around human habitations and to periodically show up in peculiar places such as yards, gardens, and the inside of buildings, most notably after rain. In many developed areas across the ranges of both species, coral snakes are more likely to be encountered than their nonvenomous mimics. ${ }^{15,19}$

In contrast to the fangs of vipers, those of the coral snakes and other elapids are short hollow structures that are permanently fixed in position on the anterior maxillary bones (proteroglyphous dentition). ${ }^{22}$ Because of their small size and short fangs, the North American coral snakes pose little risk to individuals wearing appropriate clothing and footwear. Most of the bites in humans occur on the hands and usually involve a coral snake that was intentionally picked up and handled. ${ }^{44}$ Contrary to popular urban legends, coral snakes are quite capable of delivering a potentially fatal bite without having to "chew" on the victim for a prolonged period of time.

Coral snakes are quick, agile snakes that, like their close relatives the cobras, mambas, and taipans, pack deadly neurotoxic venom. Large specimens have been documented to carry up to 7 lethal doses of venom for an average-sized adult human. ${ }^{45}$ Coral snake venom is rich in peptides that interact with nicotinic acetylcholine receptors and effectively block neurotransmission, resulting in ascending flaccid paralysis, reduced nociception, and eventually respiratory paralysis. ${ }^{17,44,46}$ Because of the shallow depth of fang penetration, the spread of venom is primarily through lymphatics. ${ }^{44}$

\section{First aid for coral snake bite}

Because of the coral snake's (Micrurus spp) short fangs and venom that is primarily a systemic neurotoxin, the triage and treatment of bitten victims is quite different 
from that recommended for victims of pit viper bites. Studies on elapid snakebites involving Australian species with neurotoxic venoms have shown that pressure immobilization bandaging of the affected limb can effectively impede the egress of toxins from the bite site and delay the onset of life-threatening systemic involvement. ${ }^{47,48}$ The recommended technique is to start wrapping from the distal portion of the limb and cover the entire extremity, which is subsequently immobilized with a splint or sling. The goal in applying the wrap is to impede lymphatic flow by attaining the target interstitial tissue pressure of 40 to $70 \mathrm{~mm} \mathrm{Hg}$ in an upper extremity or 55 to $70 \mathrm{~mm} \mathrm{Hg}$ in a lower limb. ${ }^{49}$ Experimental studies have documented that attaining the recommended pressure levels can be technically difficult and suggest that effective use of this method may require extensive training and experience. ${ }^{49}$ Because of this, the lack of case reports, and time-wastage concerns, the recommended use of this technique as a routine first-aid measure remains controversial. ${ }^{10}$ Although case reports documenting the efficacy of this method with American coral snake bites are lacking, the results of a recently published experimental study that used a swine model suggest that this technique may be a valuable first-aid measure ${ }^{50}$ Because of the potential for significant delays in the transport of bite victims out of disaster-stricken areas as well as possible antivenom supply and distribution difficulties in hurricane-stricken areas, properly training emergency-response personnel in the application of pressure immobilization bandages could be valuable to personnel deployed into regions harboring coral snakes. All coral snake bite victims should be transported to the nearest medical treatment facility as soon as possible..$^{8,10}$

Because there is rarely any observable local tissue injury with coral snake bites and the onset of neurologic signs and symptoms of envenomation can be delayed for as long as 12 hours, all cases of confirmed coral snake bites should be promptly treated with coral snake antivenom by a qualified physician. ${ }^{10}$ Suspected but unconfirmed cases of coral snake envenomation should be admitted and closely monitored for a minimum of 12 hours. ${ }^{10}$ Monitoring should focus on the presence or absence of neurologic signs and symptoms and frequent assessment of oxygen saturation and ventilatory function. ${ }^{10}$ Ventilatory support may be required with some patients. ${ }^{10}$ Once the symptoms of envenomation become apparent, they may progress precipitously and can be difficult to reverse. ${ }^{44}$ Consultation with a regional poison control center (National Hotline (800)222-1222) is recommended. Although it is no longer in active production, the only antivenom product available in the United States for the treatment of eastern and Texas coral snake bites is the equine-derived anti-Micrurus fulvius antivenom (Wyeth-Ayerst, Marietta, PA).

\section{Snakebite prevention}

The widespread destruction, extensive environmental perturbation, flooding, and austere conditions associated with a hurricane strike often bring people and snakes together under unusual circumstances. Therefore, hurricanes are sometimes associated with abrupt increases in the incidence of snakebites. $1,3,4,6$

There are a number of things that emergency-response personnel deploying into recently afflicted areas can do to prevent snake-related accidents. First, potential responders should familiarize themselves with all the indigenous species, their habits, and their medical significance before entering an affected area. Knowing what to expect in terms of potentially dangerous fauna could be invaluable to avoiding snakes, handling bite cases, and reducing snake-associated fear and anxiety.

Once on site, all personnel should avoid putting their hands and feet in places that cannot be visually inspected for snakes. When moving debris, workers should wear protective gloves and exercise care not to blindly place their fingers under the edges of such materials. The safest way to cross obstacles such as fallen trees or other large pieces of debris is to step up onto the structure, check for snakes and other hazards on the opposite side, and then carefully step into the visually cleared area. When traversing floodwater, great care should be taken to avoid blind contact with brush or limbs projecting over or out of the water. Snakes displaced by high water will often climb onto such structures and may be concealed by foliage (Figure 1B).

Wearing appropriate protective clothing can provide some level of protection against snakebites. Minimally, this should include loose-fitting trousers, long-sleeved shirts, and boots. ${ }^{30}$ For added protection against the entry of snakes or arthropods into pant legs, the trousers should be bloused. Wearing clothing in this manner provides the individual with several protective features against venomous snakes, including mechanical protection against bites, limiting the heat signature of the body, diverting fangs away from the skin, and limiting the depth of fang penetration if bitten. ${ }^{30}$

In the event that a venomous or unidentified snake is encountered in the field, it is best to slowly move out of the snake's strike range. As a general rule of thumb, the maximal strike distance of most snakes is approximately one half of their body length, so maintaining a distance of approximately 1 body length is sufficient to confer safety. Snakes that need to be identified should be pho- 
tographed from a safe distance. Digital cameras or cell phones could be invaluable tools for this purpose.

\section{Conservational concerns}

Although venom likely evolved as a means to kill and in some cases partially digest prey, recent research has documented some reptile and arthropod venoms to be rich sources of disintegrin peptides and other potentially valuable biomolecules that can serve as potent modulators of chronic diseases, including tumor metastasis and angiogenesis, ${ }^{51}$ blood clot formation, ${ }^{52}$ postangioplasty vascular restenosis, ${ }^{53}$ and the progression of hepatic fibrosis. ${ }^{54}$ In addition to being a potential source of valuable pharmaceuticals, snakes are highly efficient predators of pestiferous rodent species and play a vital role in their control. Because of these and other reasons, including personal safety, snakes encountered in the field should be treated with respect and left alone.

Unfortunately, because of human population expansion, development, habitat encroachment, and other factors, many species have been reported to be declining at an alarming rate. A p leucostoma, for instance, has been extirpated in southwest Texas and parts of Missouri and is now a protected species in the state of Indiana. The eastern diamondback rattlesnake, the timber rattlesnake, and the massasaugas have all become rare over much of their ranges, and the latter 2 species are now protected in several states. ${ }^{15,19}$ The tremendous environmental perturbation associated with a hurricane and the many close encounters between humans and snakes in the aftermath are undoubtedly detrimental to the survival of both. The escape of exotic species and their associated pathogens from man-made facilities, the liberation of toxic pollutants, and displacement from the animals' preferred habitats are just some of the storm-associated factors that can have a detrimental effect on native fauna, including snakes. The needless killing of snakes and other animals should be discouraged under any conditions. Conservational efforts in the form of understanding and tolerance, land preservation, a reduction in pollution, and perhaps captive-breeding programs are desperately needed to save these unusual and potentially valuable species from extinction.

\section{Acknowledgments}

The authors would like to thank John Willson, Michael Smith, Joe Forks, and Christina Wozniak for the excellent high-quality images they contributed to this manuscript and to Dr Whitfield Gibbons for his input and assistance with editing. We would also like to thank Eric Grafman from the Centers for Disease Control and Pre- vention image library for all of his assistance with the development of the composite figures.

\section{References}

1. Lee LE, Fonseca V, Brett KM, et al. Active morbidity surveillance after Hurricane Andrew-Florida 1992. JAMA. 1993;270:591-594.

2. Kerber R. An increase in poisonous snakebites feared: officials check antidote supply. Available at: http://www. boston.com/news/weather/articles2005/09/14/an_increase_ in_poisonous_snakebites_feared/. Accessed October 16, 2005.

3. Broward County Medical Examiner. Hurricane-related medical problems. Available at: http://broward.org/ medical/mei00281.htm. Accessed October 16, 2005.

4. Green L, Ulferts A. Several health risks rise along with storm watchers. St Petersburg Times OnLine. Available at: http://sptimes.com/2004/09/05/weather/several health risks.shtml. Accessed October 16, 2005.

5. North Carolina Department of Health and Human Services, Carolinas Poison Control Center. Floyd causing increased risk of snakebites. Available at: http://www.dhhs. state.nc.us/pressrel/9-24-99c.htm. Accessed October 16, 2005.

6. Roth D. Texas hurricane history: late 20th century. Available at: http://srh.noaa.gov/lch/research/txhur.htm. Accessed October 16, 2005.

7. Kischor MC, Perry DC. Guide to the Use of the Wind Load Provisions of ASCE 7-98. Reston, VA: American Society of Civil Engineers Press; 1998.

8. Russell, FE. Snake Venom Poisoning. Great Neck, NY: Scholium International Inc; 1983.

9. Lawrence WT, Giannopoulos A, Hansen A. Pitviper bites: rational management in locales in which copperheads and cottonmouths predominate. Ann Plast Surg. 1996;36:276285.

10. Gold BS, Dart RC, Barish BA. Bites of venomous snakes. N Engl J Med. 2002;347:347-356.

11. Jasper EH, Miller M, Neuberger KJ, Widder PC, Snyder JW, Lopez BL. Venomous snakebites in an urban area: what are the possibilities? Wilderness Environ Med. 2000; 11:168-171.

12. Mattison C. Rattler; A Natural History of Rattlesnakes. New York, NY: Sterling Publishing; 1996.

13. Gloyd HK, Conant R. Snakes of the Agkistrodon Complex: A Monograph Review. Oxford, OH: Society for the Study of Amphibians and Reptiles; 1990.

14. Klauber LM. Rattlesnakes: Their Habits, Life Histories, and Influence on Mankind. 2nd ed. Los Angeles: University of California Press; 1997.

15. Tennant A. A Field Guide to Texas Snakes. 2nd ed. Houston, TX: Gulf Publishing Company; 1997.

16. Price AH. Poisonous Snakes of Texas, Austin: University of Texas Press; 1998.

17. Campbell JA, Lamar WW. Venomous Reptiles of the West- 
ern Hemisphere. Ithaca, NY: Cornell University Press; 2004.

18. Gibbons W, Dorcas M. Snakes of the Southeast. Athens: University of Georgia Press; 2005.

19. Tennant A. A Field Guide to Snakes of Florida. Houston, TX: Gulf Publishing Company; 1997.

20. Conant R. A Field Guide to the Reptiles and Amphibians of Eastern and Central North America. 3rd ed. Boston, MA: Houghton Mifflin Company; 1991.

21. Brattstrom BH. Evolution of the pit vipers. Trans San Diego Soc Nat Hist. 1964;13:185-268.

22. Porter KR. Herpetology. Philadelphia, PA: WB Saunders Company; 1972.

23. Knight A, Densmore LD, Rael ED. Molecular systematics of the Agkistrodon complex. In: Campbell JA, Brodie ED Jr, eds. Biology of the Pitvipers. Tyler, TX: Selva; 1992: 49-69.

24. Parkinson CL, Zamudio KR, Greene HR. Phylogeny of the pitviper clade Agkistrodon: historical ecology, species status and conservation of cantils. Mol Ecol. 2000;9:411420.

25. Schier JG, Wiener SW, Tiuger M, Nelson LS, Hoffman RS. Efficacy of Crotalidae polyvalent antivenin for the treatment of hognosed viper (Porthidium nasutum) envenomation. Ann Emerg Med. 2003;41:391-395.

26. Sanchez EE, Ramirez, Galan JC, et al. Cross-reactivity of three antivenoms against North American snake venoms. Toxicon. 2003;41:315-320.

27. Sanchez EE, Galan JA, Perez JC, et al. The efficacy of two antivenoms against the venom of North American rattlesnakes. Toxicon. 2003;43:357-365.

28. Richardson WH III, Tanen DA, Tong TC et al. Crotalidae polyvalent Fab (ovine) antivenom is effective in the neutralization of South American viperidae venoms in a murine model. Ann Emerg Med. 2005;45:595-602.

29. Gibbons W, Dorcas M. Defensive behavior of cottonmouths (Agkistrodon piscivorus) toward humans. Copeia. 2002;1:195-198.

30. Murdock RT, White GL Jr, Pedersen DM, DeFaller JM, Snyder CC. Prevention and emergency field management of venomous snakebites during military exercises. Mil Med. 1990;155:587-590.

31. Thorson A, Lavonas EJ, Rouse AM, Kerns WP II. Copperhead envenomations in the Carolinas. J Toxicol Clin Toxicol. 2003;41:29-35.

32. Scharman EJ, Noffsinger VD. Copperhead snakebites: clinical severity of local effects. Ann Emerg Med. 2001; 38:55-61.

33. Consroe P, Egen NB, Russell FE, et al. Comparison of a new ovine antigen binding fragment (Fab) antivenin for United States Crotalidae with the commercial antivenin for protection against venom-induced lethality in mice. Am J Trop Med Hyg. 1995;53:507-510.

34. Yarema MC, Curry SC. Envenomation by the northern blacktail rattlesnake (Crotalus molossus molussus): case report. Pediatr Emerg Care. 2005;21:40-42.

35. Rael ED, Johnson JD, Molina O, McCrystal HK. Distri- bution of a Mojave toxin-like protein in rock rattlesnake (Crotalus lepidus) venom. In: Campbell JA, Brodie ED Jr, eds. Biology of the Pitvipers. Tyler, TX: Selva; 1992:163168.

36. Spiller HA, Bosse GM. Prospective study of morbidity associated with snakebite envenomation. J Toxicol Clin Toxicol. 2003;41:125-130.

37. Miller MA, Dyer JE, Olson KR. Two cases of rattlesnake envenomation with delayed coagulopathy. Ann Emerg Med. 2002;39:348.

38. Bush SP, Cardwell MD. Mojave rattlesnake (Crotalus scutellatus sutellatus) identification. Wilderness Environ Med. 1999;10:6-9.

39. French WJ, Hayes WK, Bush SP, Cardwell MD, Bader JO, Rael ED. Mojave toxin in venom of Crotalus helleri (southern Pacific rattlesnake): molecular and geographic characterization. Toxicon. 2004;44:781-791.

40. Daltry JC, Wuester W, Thorpe RS. Diet and snake venom evolution. Nature. 1996;379:537-540.

41. Clark RF, McKinney PE, Chase PB, Walter FG. Immediate and delayed reactions to polyvalent immune Fab (ovine) antivenin. Ann Emerg Med. 2002;39:671-676.

42. Ruha AM, Curry SC, Beuhler M, et al. Initial postmarketing experience with crotalidae polyvalent immune Fab for treatment of rattlesnake envenomation. Ann Emerg Med. 2002;39:648-650.

43. Holstege $\mathrm{CP}, \mathrm{Wu} \mathrm{J}, \mathrm{Baer} \mathrm{AB}$. Immediate hypersensitivity reaction with the rapid infusion of crotalidae polyvalent immune Fab (ovine). Ann Emerg Med. 2003;39:677-679.

44. Kitchens CS, Van Mierop LH. Envenomation by the Eastern coral snake (Micrurus fulvius fulvius). A study of 39 victims. JAMA. 1987;258:1615-1618.

45. Fix JD. Venom yield of the North American coral snake and its clinical significance. South Med J. 1980;73:737-738.

46. Chrisman CL, Hopkins AL, Ford SL, Meeks JC. Acute, flaccid quadriplegia in three cats with suspected coral snake envenomation. J Am Anim Hosp Assoc. 1996;32: 343-349.

47. Sutherland SK, Coulter AR, Harris RD. Rationalisation of first-aid measures for elapid snakebite. Lancet. 1979;1: 183-186.

48. Murrell G. The effectiveness of the pressure/immobilization first aid technique in the case of a tiger snake bite. Med J Aust. 1981;2:295.

49. Norris RL, Ngo J, Nolan K, Hooker G. Physicians and lay people are unable to apply pressure immobilization properly in a simulated snakebite scenario. Wilderness Environ Med. 2005;16:16-21.

50. German BT, Hack JB, Brewer K, Meggs WJ. Pressureimmobilization bandages delay toxicity in a porcine model of eastern coral snake (Micrurus fulvius fulvius) envenomation. Ann Emerg Med. 2005;45:603-608.

51. Zhou Q, Sherman SP, Parrish C, et al. Contortrostatin, a dimeric disintegrin from Agkistrodon contortrix contortrix inhibits breast cancer progression. Breast Cancer Res Treat. 2000;61:249-260.

52. Savage B, Marzec UM, Chao BH, Harker LA, Maraganore 
JM, Ruggeri ZM. Binding of the snake venom-derived proteins applaggin and echistatin to the arginine-glycineaspatic acid and recognition sites on platelet glycoprotein IIb/IIIa. J Biol Chem. 1990;268:1066-1073.

53. Hong SY, Koh YS, Chung KH, Kim DS. Snake venom disintegrin, saxatilin, inhibits platelet aggregation, human umbilical vein endothelial cell proliferation and smooth muscle cell migration. Thromb Res. 2002;105:79-86.

54. Iwamoto H, Sakai H, Kotoh K, Nakamuta M, Nawata H. Soluble Arg-Gly-Asp peptides reduce collagen accumulation in cultured rat hepatic stellate cells. Dig Dis Sci. 1999; 44:1038-1045.

\section{WMS Publications Announcements! NOW AVAILABLE! WILDERNESS MEDICAL SOCIETY}

\section{PRACTICE GUIDELINES FOR WILDERNESS EMERGENCY CARE}

Fifth Edition

Edited by William Forgey, M.D.

\section{WILDERNESS MEDICAL SOCIETY - ANTHOLOGY}

\section{Essays and Editorials from the Journal of Wilderness Medicine and Wilderness and Environmental Medicine}

First Edition

Edited by George W. Rodway, PhD

and Robert Norris, MD

Forward by Paul S. Auerbach, MD

For purchases and/or inquiries please call 1-800-627-0629 (Int'l 785-843-1235). 